\title{
Design Considerations for Borehole Thermal Energy Storage (BTES): A Review with Emphasis on Convective Heat Transfer
}

\author{
Helge Skarphagen, ${ }^{1}$ David Banks $\mathbb{D}^{2,3}{ }^{2,3}$ Bjørn S. Frengstad $\mathbb{D}^{4},{ }^{4}$ and Harald Gether ${ }^{1}$ \\ ${ }^{1}$ Gether AS, Bakkeveien 12, N-3292 Stavern, Norway \\ ${ }^{2}$ School of Engineering, James Watt Building (South), Glasgow University, Glasgow G12 8QQ, UK \\ ${ }^{3}$ Holymoor Consultancy Ltd., Chesterfield, Derbyshire S40 4BW, UK \\ ${ }^{4}$ Department of Geoscience and Petroleum, Norwegian University of Science and Technology (NTNU), N-7491 Trondheim, Norway
}

Correspondence should be addressed to David Banks; david.banks@glasgow.ac.uk

Received 27 September 2018; Accepted 13 January 2019; Published 22 April 2019

Guest Editor: Antonio Galgaro

Copyright (c) 2019 Helge Skarphagen et al. This is an open access article distributed under the Creative Commons Attribution License, which permits unrestricted use, distribution, and reproduction in any medium, provided the original work is properly cited.

\begin{abstract}
Borehole thermal energy storage (BTES) exploits the high volumetric heat capacity of rock-forming minerals and pore water to store large quantities of heat (or cold) on a seasonal basis in the geological environment. The BTES is a volume of rock or sediment accessed via an array of borehole heat exchangers (BHE). Even well-designed BTES arrays will lose a significant quantity of heat to the adjacent and subjacent rocks/sediments and to the surface; both theoretical calculations and empirical observations suggest that seasonal thermal recovery factors in excess of $50 \%$ are difficult to obtain. Storage efficiency may be dramatically reduced in cases where (i) natural groundwater advection through the BTES removes stored heat, (ii) extensive free convection cells (thermosiphons) are allowed to form, and (iii) poor BTES design results in a high surface area/volume ratio of the array shape, allowing high conductive heat losses. The most efficient array shape will typically be a cylinder with similar dimensions of diameter and depth, preferably with an insulated top surface. Despite the potential for moderate thermal recovery, the sheer volume of thermal storage that the natural geological environment offers can still make BTES a very attractive strategy for seasonal thermal energy storage within a "smart" district heat network, especially when coupled with more efficient surficial engineered dynamic thermal energy stores (DTES).
\end{abstract}

\section{Introduction and Terminology}

The term "thermogeology" $[1,2]$ has been applied to the science of the occurrence, movement, and exploitation of heat in the earth's subsurface. The ground can be used as a sink or source of heat to provide heating, cooling, or dehumidification to residential and commercial spaces or to industrial or horticultural processes-a technological practice known as ground source heating and cooling (GSHC). This is often, but not always, achieved by the use of ground source heat pumps (GSHP).

Most rocks and saturated sediments have rather high volumetric heat capacities-typically around $2 \mathrm{MJ} \mathrm{m}^{-3} \mathrm{~K}^{-1}$. That of water is even higher-c. $4.19 \mathrm{MJ} \mathrm{m}^{-3} \mathrm{~K}^{-1}$. Because of these high values, the ground, and the groundwater it contains, can be used as thermal store or "accumulator." Because the ground beneath a development site has a huge volume and thermal capacity, and because accessing it requires capital-intensive drilling and geoengineering, underground thermal energy storage (UTES) is typically used for the large-scale seasonal storage of heat that is difficult to achieve using conventional surface technologies. UTES can be subdivided into two categories:

(1) Borehole thermal energy storage (BTES), where a field of borehole heat exchangers (BHE) exchanges heat with the surrounding rock or sediment mass, predominantly by processes of conduction. In typical cases, the surplus heat stored during the summer months is extracted for space heating usage in winter (and/or vice versa in the case of "coolth"). One of the earliest BTES pilot projects was the Luleåvärme 
Project, in Luleå, Sweden, which operated from 1983 to 1989. Here, surplus industrial heat from a steel plant, supplied at temperatures of $70-80^{\circ} \mathrm{C}$, was seasonally stored in a BTES array of 120 number $65 \mathrm{~m}$ deep boreholes $(10 \times 12$ array $)$ in granitic gneisses, spaced at c. $4 \mathrm{~m}$ and with an array volume of c. $115000 \mathrm{~m}^{3}$ [3-7]. The annual recharge of heat was some $2.3 \mathrm{GWh}$, with around $1 \mathrm{GWh}$ recovered annually. The temperature within the BTES rock mass was in excess of $50^{\circ} \mathrm{C}$, reaching as high as $65^{\circ} \mathrm{C}$

(2) Aquifer thermal energy storage (ATES), which typically involves paired doublets of extraction and reinjection wells, and where warm or cold water is introduced (via the reinjection wells) under excess head [8-10]. Heat is thus largely manipulated within the aquifer volume by means of "forced (head driven) convection" or "advection." Early trials of hightemperature storage of hot $\left(80-90^{\circ} \mathrm{C}\right)$ water took place in an interbedded sand/clay aquifer sequence at Mobile, Alabama, USA [11, 12]. A well-publicised, recent, lower-temperature example of ATES is at Arlanda Airport, Sweden [13, 14].

This paper will focus predominantly on seasonal storage of heat via BTES. Such heat storage is especially attractive in strongly seasonal climates, and the paper will particularly focus on BTES in the fractured crystalline rock terrain prevalent in Fennoscandia and Canada, although the general principles also apply to porous medium aquifers and more temperate climates. Comprehensive analyses and reports on the theory and practice of UTES and BTES were produced in the 1980s and 1990s, which are still regarded as key literature on the topic today, notably

(i) Gerardus van Meurs' thesis on seasonal heat storage in conventional porous sediments [15]

(ii) Claesson et al.'s report on analytical solutions to ground source heat problems, including seasonal storage in BTES [16]

(iii) Göran Hellström's analysis of the thermophysics of borehole heat exchangers and their application to subsurface heat storage [17]

(iv) Bo Nordell's thesis on the design and optimisation of BTES systems [3]

Documented examples of established BTES include

(i) the summer harvesting of solar heat (by solar thermal rooftop collectors) at a housing development in Drake Landing, Canada [18-20]. The BTES array comprises a cylindrical array of 144 boreholes to $35 \mathrm{~m}$ depth (volume $34,000 \mathrm{~m}^{3}$ ).

(ii) A similar district heating system, relying on summer harvesting of solar heat and storage in a BTES array comprising 100 boreholes to $65 \mathrm{~m}$ depth, spaced at $3 \mathrm{~m}$, (volume $65,000 \mathrm{~m}^{3}$ ) in crystalline bedrock at Anneberg, near Stockholm, Sweden [21]

(iii) Another district heating system at Neckarsulm, Germany, storing summer solar thermal energy at temperatures of up to $80^{\circ} \mathrm{C}$ in a rock mass, via a BTES system of volume $63,360 \mathrm{~m}^{3}$ comprising (as of 2006) 528 borehole heat exchangers to depth $30 \mathrm{~m}$ [22]. The borehole spacing is as little as $2 \mathrm{~m}$ [23]

(iv) Richard Stockton College, New Jersey, USA, where a 1.2 million $\mathrm{m}^{3}$ BTES system services loads of up to $5 \mathrm{MW}$ and reportedly comprised an array of 400 boreholes of $135 \mathrm{~m}$ depth [24]

(v) The Kemicentrum, Lund, Sweden [25], which utilises an array of 153 boreholes to $230 \mathrm{~m}$ deep to support a heating load of $6790 \mathrm{MWh}$ (peak load c. $5 \mathrm{MW}$ ) and a cooling load of $5400 \mathrm{MWh}$ (peak load c. $3 \mathrm{MW})$.

(vi) Avantor, Nydalen Industry Park, Oslo, Norway $[26,27]$, utilises a BTES system of 180 boreholes to $200 \mathrm{~m}$ depth in crystalline bedrock, spaced at $7 \mathrm{~m}$, to deliver c. $6 \mathrm{MW}$ heating effect and $9.5 \mathrm{MW}$ cooling effect

(vii) An archive building in Shanghai, which operates a GSHC system of up to $1 \mathrm{MW}$ capacity, with a strong element of BTES, utilising 280 boreholes of $80 \mathrm{~m}$ depth [28].

(viii) The high-temperature BTES at Emmaboda, Sweden $[7,29,30]$, which has, since its initiation in 2010, stored around $10 \mathrm{GWh}$ of industrial waste heat (with source temperatures ranging from 58 to $90^{\circ} \mathrm{C}$, but supplied to the BTES at up to $55^{\circ} \mathrm{C}$ ) in a $10 \times 14$ array of 140 boreholes, spaced at $\mathrm{c}$. $4 \mathrm{~m}$, drilled to $150 \mathrm{~m}$ deep in bedrock predominantly comprising granodiorite. The BTES storage volume was some $323,000 \mathrm{~m}^{3}$, while the ground temperature within the BTES array had reached $40-45^{\circ} \mathrm{C}$ by 2015 . The BTES is divided into 7 quasi-concentric sections that can be individually operated

Further reviews of the state of the art of BTES have been extensively published by [31-43].

A borehole heat exchanger (BHE) is typically based on a borehole drilled at between 100 and $150 \mathrm{~mm}$ diameter. Depths can be anything up to $350 \mathrm{~m}$ : 35 to $150 \mathrm{~m}$ is typical for continental Europe, but depths in excess of $200 \mathrm{~m}$ are rather common in the crystalline rock terrain of Fennoscandia and the Faroes. The borehole accommodates some form of heat exchange pipe. This often takes the form of a Ushaped tube (i.e., upflow and downflow shanks). Alternatively, coaxial pipes or double-U pipes can be installed. A heat transfer fluid is circulated (by pumping) around the borehole heat exchanger. The heat transfer fluid is often based on a solution of antifreeze (ethanol is common in 
Fennoscandia; ethylene or propylene glycol are commoner in the UK), together with additives, such as biocides and corrosion inhibitors. In high-temperature BTES, where the temperature of the fluid never approaches $0^{\circ} \mathrm{C}$, then simple water (possibly with additives) can be utilised. If the heat transfer fluid is warmer than the surrounding rocks, heat is rejected to the geological environment; if the heat transfer fluid is cooler, then heat will be extracted. The heat transfer fluid circulates to a heat exchanger or heat pump at the surface, by means of which space cooling, space heating, or industrial/agricultural cooling are performed.

A BHE U-tube is commonly constructed of highdensity polyethylene (HDPE) or cross-linked polyethylene (PEX) and is of $40 \mathrm{~mm}$ (or sometimes $32 \mathrm{~mm}$ ) outside diameter (OD). For higher-temperature BTES applications, the choice of material can be important as some polyethylene types lose strength as temperature increases. In high-temperature BTES systems, PEX, PE-RT (polyethylene of raised temperature resistance) materials may be preferred [38] and steel pipes may also become attractive. In high-temperature BTES systems, the thermal expansion of the ground in the BTES may become significant and ground heave will need to be considered in any operational risk assessment [2].

In Fennoscandian "hard" crystalline rocks (e.g., gneisses, granites, schists), the BHE borehole is typically unlined (although a limited length of surface casing is typically installed for stability). In such low-permeability rocks, in a wet climate, the water table is often close to the surface and the boreholes are naturally groundwaterfilled. It is this groundwater that provides the thermal contact between the heat exchange pipe and the rocks in the borehole walls.

In low-permeability crystalline Fennoscandian rock terrains, an "open coaxial" arrangement is sometimes used, employing a single pipe down the centre of the borehole, and using the surrounding borehole space as the outer coaxial conduit: in this case, the heat exchange fluid is in direct contact with the borehole wall, leading to very efficient heat exchange [29].

In other geological environments (e.g., where the rocks are not fully lithified and self-supporting) or where the water table is low, then the borehole can be backfilled with a low-permeability thermally enhanced grout, which provides a thermally conductive contact between the heat exchange pipe and the geological environment. The borehole structure itself thus possesses a "thermal resistance" $\left(R_{\mathrm{b}}\right)$ to heat flow.

\section{Defining Thermal Efficiency: Ambient and High-Temperature BTES}

"Heat" is a mathematical concept (unlike water, whose molecules can be isotopically labelled, or which can be marked with a chemical tracer), and the recovery of "particles" of heat cannot be empirically measured. We must thus be very careful when defining exactly what we mean by thermal storage or recovery efficiency.
Where a high-temperature source of waste heat exists, which is producing heat even at times of low demand (waste incinerator, combined heat and power (CHP) plant, and metallurgical industry), it is possible to store this waste heat underground via a BTES array. During the initial years of operation, the BTES store (and the rock it encloses) is "charged up" with heat to the operating temperature (Figure 1), a process which often involves recharging significantly more heat to the ground than is extracted. During this phase, the temperature field around the BTES evolves; the ground surrounding the BTES warms up, and the temperature contrast between the BTES and the surrounding ground decreases. At some stage, typically after 3-6 years, some kind of quasi-steady state will be achieved, where the operating temperature is reached and the annual heat loss to the surface and surrounding rocks becomes stable; this marks the start of the operational (steady-state phase). In fact, however, it will typically take many decades for a true steady state to be achieved in the far temperature field. During an annual cycle (assuming it is a seasonal heat store), a quantity of heat is recharged to the BTES, and a quantity of heat is extracted (normally, during winter). If the system has entered a quasi-steady state and the longterm average temperature of the BTES is stable (it will, of course, vary over an annual cycle), then the difference between the annual recharge and annual extraction can be taken to be the heat loss to the surrounding ground or the surface. This heat loss will intuitively be

(i) proportional to the temperature difference between the edge of the BTES array and the ambient ground temperature

(ii) roughly proportional to the thermal conductivity of the ground

(iii) related to the geometry of the BTES array (e.g., the surface area to volume ratio) and to any insulation applied to the BTES

In such a case, the thermal recovery factor $\eta_{\mathrm{E}}$ is relatively easy to define: it is the ratio of the heat recovered to the heat recharged over an annual cycle (or longer period).

However, there is another type of BTES, operating at less extreme-approximately ambient-temperatures. Such a scheme is usually used at a business or building that has predominantly cooling (heat rejection needs) in summer, balanced with a similar heating demand in winter; e.g., many office buildings, hospitals, and greenhouse complexes. In such schemes, a heat pump will draw heat from the building in summer via a chiller circuit and reinject it, via the heat pump condenser, to the ground, at maybe $25^{\circ} \mathrm{C}$. In winter, the BTES will be coupled to the heat pump's evaporator and a chilled heat transfer fluid (maybe a few degrees above $0^{\circ} \mathrm{C}$ ) will extract heat from the ground. Thus, the average temperature of the heat store will be around the ambient ground temperature, extreme temperatures are avoided, and the heat pump operates very efficiently. The ground is thus prechilled for the summer cooling season and preheated (by rejected summer waste heat) for the winter heating 


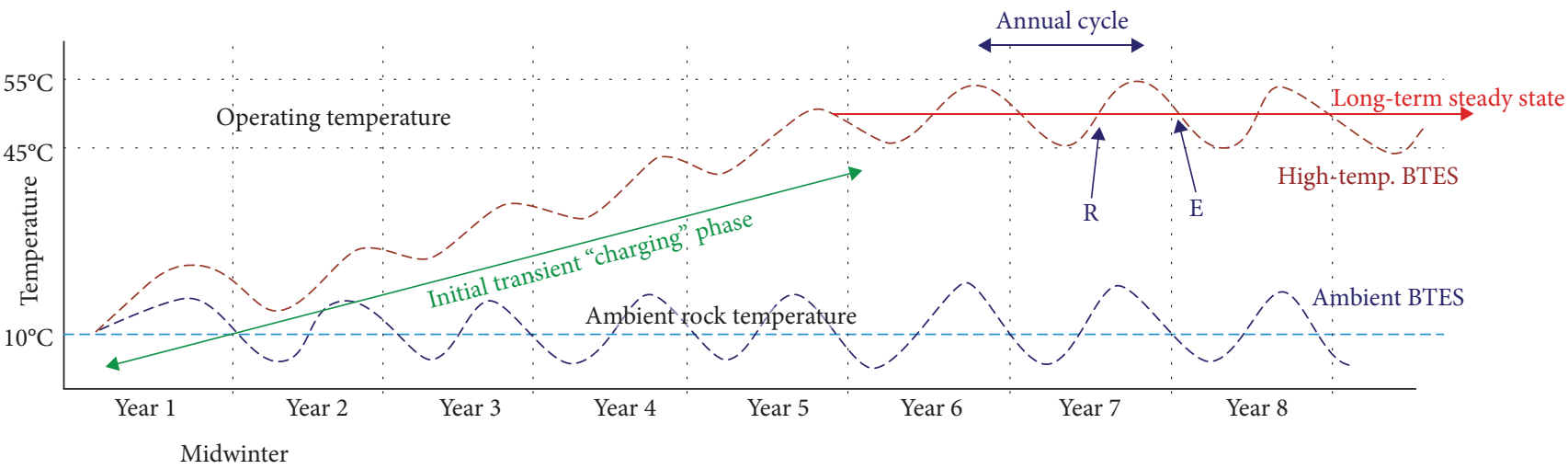

FIGURE 1: Schematic diagram of temperature evolution in a high-temperature BTES system, operating at around $45-55^{\circ} \mathrm{C}$, and in an ambient BTES system serving balanced heating and cooling demands. Ambient rock temperature $=10^{\circ} \mathrm{C}$. Temperatures are only indicative and will depend on exactly where within the BTES they are measured. $\mathrm{R}=$ recharge of heat during summer and autumn; $\mathrm{E}=$ extraction of heat in winter and spring.

season. In this case, the simple thermal recovery factor $\eta_{\mathrm{E}}$ is difficult to apply as heat is not, in a sense, "lost." In these cases, it is perhaps more meaningful to compare the ambient BTES with the performance of a similar scheme where no seasonal storage is practiced, but where heat is solely extracted from the ground in winter, but not replenished in summer. This paper thus defines

(i) the thermal recovery advantage as the additional amount of heat extracted from a BTES, relative to the amount that can be extracted in a base case where "recharge" of heat is not practised

Finally, in this paper we will also consider the rise in temperature of a BTES if heat is simply charged into the BTES year on year, with no extraction.

$$
\text { Thermal accumulation } \begin{aligned}
(\mathrm{J})= & \text { Temperature increase }(\mathrm{K}) \\
& \times \operatorname{BTES} \text { volume }\left(\mathrm{m}^{3}\right) \times c_{\mathrm{v}},
\end{aligned}
$$

where $c_{\mathrm{v}}$ is the volumetric heat capacity of the rock $\left(\mathrm{Jm}^{-3} \mathrm{~K}^{-1}\right)$.

The thermal accumulation is the amount of heat that has been retained within the BTES during the period in question. As the temperature of the BTES increases, the heat loss to the surrounding environment will also increase; the rate of heat accumulation will decrease and the rate of temperature rise will decline. We will discuss a rather crude parameter:

(i) The thermal accumulation efficiency, defined as the estimated year on year accumulation of heat in a BTES array, calculated from the slope of the temperature evolution under heat injection only conditions, divided by the total amount recharged

We will begin our consideration of BTES by examining borehole heat exchangers and ambient BTES.

\section{Heat Extraction and Storage via Borehole Heat Exchangers (BHE)}

The temperature field around a borehole heat exchanger can be simulated as a line source (or sink) of heat $[44,45]$. In the short-medium term, this is adequately represented by the "line source" heat equation (equation (2)), apparently first deduced by Whitehead in 1927 [46] and later utilised in the context of groundwater abstraction by Clarence Lubin and Charles Theis [47]:

$$
\theta=\theta_{0}+\frac{q}{4 \pi \lambda} E i(u)
$$

where

(i) $\theta$ is the average temperature at a given radial distance $(r)$ from the borehole axis at any time $(t)$ following commencement of heat rejection or extraction $\left({ }^{\circ} \mathrm{C}\right.$ or $\left.\mathrm{K}\right)$

(ii) $\theta_{0}$ is the average temperature of the rock mass along the length of the borehole, prior to commencement of heat rejection or extraction $\left({ }^{\circ} \mathrm{C}\right.$ or $\left.\mathrm{K}\right)$

(iii) $q$ is the rate of heat rejection (positive) or extraction (negative) in watts per metre of borehole $\left(\mathrm{W} \mathrm{m}^{-1}\right)$

(iv) $\lambda$ is the thermal conductivity of the rock $\left(\mathrm{W} \mathrm{m}^{-1} \mathrm{~K}^{-1}\right)$

(v) $E i$ is the exponential integral function

(vi) $u=r^{2} c_{v} / 4 \lambda t=r^{2} / 4 \alpha t$ (dimensionless)

(vii) $\alpha$ is the thermal diffusivity of the rock $=\lambda / c_{v}\left(\mathrm{~m}^{2} \mathrm{~s}^{-1}\right)$

The average temperature of the heat transfer fluid (i.e., the average of the flow and return temperatures to/from the $\mathrm{BHE}=\theta_{b}$ ) is given by simply calculating the temperature at the borehole wall (radius $r_{\mathrm{b}}$ ) and adding 
a constant term to account for the borehole thermal resistance $\left(R_{\mathrm{b}}\right)$ :

$$
\theta_{\mathrm{b}}=\theta_{0}+q R_{\mathrm{b}}+\frac{q}{4 \pi \lambda} \operatorname{Ei}\left(u_{\mathrm{b}}\right)
$$

where

(i) $\theta_{\mathrm{b}}$ is the average temperature of the heat transfer fluid at any time $(t)$ following commencement of heat rejection or extraction $\left({ }^{\circ} \mathrm{C}\right.$ or $\left.\mathrm{K}\right)$

(ii) $R_{\mathrm{b}}$ is the borehole thermal resistance $\left(\mathrm{km} \mathrm{W}^{-1}\right)$

(iii) $u_{\mathrm{b}}=r_{\mathrm{b}}^{2} c_{\mathrm{v}} / 4 \lambda t=r_{\mathrm{b}}^{2} / 4 \alpha t$ (dimensionless)

(iv) $r_{\mathrm{b}}$ is the radius of the borehole into which the BHE is installed $(\mathrm{m})$

Let us imagine a single borehole heat exchanger, installed in a borehole $100 \mathrm{~m}$ deep and $120 \mathrm{~mm}$ diameter, with a borehole thermal resistance of $0.08 \mathrm{~km} \mathrm{~W}^{-1}$ (quite typical figures for a well-constructed, thermally efficient BHE). Let us further assume that the rock has a thermal conductivity of $2.48 \mathrm{~W} \mathrm{~m}^{-1} \mathrm{~K}^{-1}$ and a volumetric heat capacity of $2.4 \mathrm{MJ} \mathrm{m}^{-3}$ $\mathrm{K}^{-1}$ and that the average initial rock temperature along the borehole length is $11^{\circ} \mathrm{C}$ (reasonably typical for an acidic igneous rock or sandstone in temperate Europe). Let us further assume a thermal load scenario (Scenario 1) as follows:

(i) For four months in summer (May-August), $9000 \mathrm{kWh}(32400 \mathrm{MJ})$ of surplus heat is rejected to the BHE. This works out at an average rate of $3.08 \mathrm{~kW}$, or $q=30.8 \mathrm{~W} \mathrm{~m}^{-1}$. Days 0 to 122

(ii) For the next two months (Sept.-Oct.), the borehole does not extract or reject heat. Days 122 to 183

(iii) For four months of winter (November-February), $9000 \mathrm{kWh}(32400 \mathrm{MJ})$ of heat is extracted from the borehole (presumably by means of a heat pump, given the low temperatures involved). This works out at an average rate of $-3.08 \mathrm{~kW}$, or $q=-30.8 \mathrm{~W}$ $\mathrm{m}^{-1}$. Days 183 to 304

(iv) Thereafter, the borehole remains inoperative

This will be compared in the following discussion with a second scenario (scenario 2-no heat recharge), where there is no initial heat rejection phase, but merely

(i) $9000 \mathrm{kWh}(32400 \mathrm{MJ})$ of heat extraction at a constant rate from November to February. This works out at an average rate of $-3.08 \mathrm{~kW}$, or $q=-30.8 \mathrm{~W} \mathrm{~m}^{-1}$. Days 183 to 304

Application of equations (2) and (3) in a spreadsheet environment allows us to calculate the temperature of the heat transfer fluid and the temperature at the borehole wall and at various radial distances into the rock mass from the borehole axis (Figure 2). Figure 3 plots this data against radial distance for various times, and it can be seen that temperature decays approximately with the logarithm of radial distance from the borehole.

It will also be noted that the difference in average heat transfer fluid temperature between scenario 1 (with the initial injection of $9000 \mathrm{kWh}$ of heat in months 1-4) and scenario 2 (no heat recharge; only heat extraction in months 6-10) is typically only a little over $0.5^{\circ} \mathrm{C}$. In other words, the benefit of recharging $9000 \mathrm{kWh}$ of heat to a single borehole during summer months is typically a slightly elevated heat transfer fluid temperature during the subsequent heat extraction phase, to the tune of some 0.5 to $1^{\circ} \mathrm{C}$. This would result in a slightly improved heat pump performance, and one can thus argue that the recharged heat has been recovered, but not in an especially noticeable or economically advantageous manner. In Figure 4, the temperature difference between the scenarios with and without heat recharge is shown as a function of distance at the end of the heat extraction season (day 304). It can be seen that the temperature difference becomes very small $\left(<0.1^{\circ} \mathrm{C}\right)$ beyond $12 \mathrm{~m}$, and in the immediate vicinity of the borehole, it is around $0.5^{\circ} \mathrm{C}$. One can calculate the "stored" heat that this temperature difference $(\Delta \theta)$ represents by multiplying the volume of successive radial sections by the volumetric heat capacity and the temperature difference $\left(2 \pi r H \times \delta r \times c_{\mathrm{V}} \times \Delta \theta\right)$. This calculation verifies that almost all the $9000 \mathrm{kWh}$ recharged heat is stored in the rock around the borehole within the zone $r=0.06$ to $20 \mathrm{~m}$. The bulk of the heat is, however, stored in the zone $3-10 \mathrm{~m}$, with the maximum quantity of stored heat at around $r=6-7 \mathrm{~m}$ (Figure 4).

\section{Thermal Recovery Advantage-Single Borehole}

To attempt to quantify the utility of the heat recharge in scenario 1 , one can compare the operational heat transfer fluid temperature during scenario 2 without heat injection $\left(-0.18^{\circ} \mathrm{C}\right.$ at day 304$)$ and then increase the heat extraction rate in scenario 1 (with heat recharge) until a similar heat transfer fluid temperature is achieved-i.e., our previously defined thermal recovery advantage (see above). It is found that a heat injection (months 1-4) of $9000 \mathrm{kWh}$, followed by a heat extraction (months 6-10) of $9500 \mathrm{kWh}$, gives a similar heat transfer fluid temperature profile to that achieved by the extraction of $9000 \mathrm{kWh}$ heat (no heat recharge). Thus, one can say that the effect of recharging $9000 \mathrm{kWh}$ of heat to a single BHE in summer is to allow the equivalent of an additional extraction of $500 \mathrm{kWh}$ of heat during winter: a thermal recovery advantage of only $5.6 \%$.

One could reasonably argue that this is unduly pessimistic. In the scenario where balanced heat recharge and extraction are practised year on year, there is no long-term downwards "drift" in temperatures. In the scenario with winter heat extraction only, temperatures will progressively (though slowly) decline year upon year. In fact, one can calculate that at the end of the $15^{\text {th }}$ heat extraction season, the average heat transfer fluid temperature would be $-1.44^{\circ} \mathrm{C}$. In the scenario with heat recharge of $9000 \mathrm{kWh}$ during summer, one could extract $10650 \mathrm{kWh}$ during winter to yield a similar 


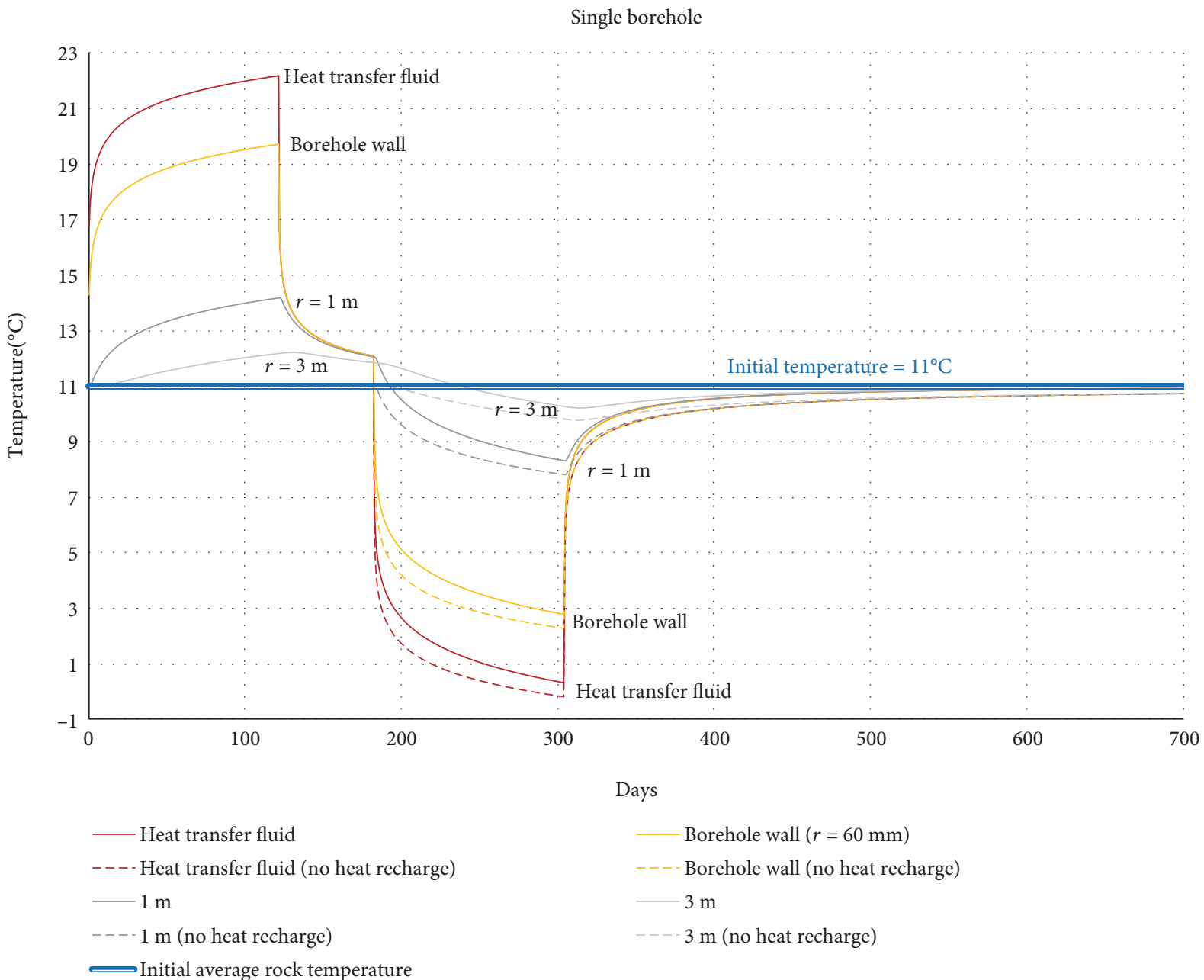

Figure 2: Calculated average heat transfer fluid temperature and temperature at the borehole wall $(r=0.06 \mathrm{~m})$ and in the rock mass at radial distances of $1 \mathrm{~m}$ and $3 \mathrm{~m}$ from the borehole axis, for heat injection/abstraction scenario (scenario 1) specified in text.

fluid temperature-a thermal recovery advantage of $1650 \mathrm{kWh}(18.3 \%)$.

\section{Larger BHE Arrays for Thermal Storage}

However, due to the relatively modest improvements in operating temperature, it is not normally considered efficient to use single BHEs or small arrays of $\mathrm{BHE}$ to store heat (although it may arguably still be worthwhile if the surplus injected heat has little or no alternative value and can be recharged to the ground for little additional cost). This conclusion concurs with that of Kjellsson et al. [48], who also found that summer solar heat recharged to a single borehole "leaks" away rapidly_small thermal advantages might accrue, but these might easily be counterbalanced by the additional costs of circulation pumps, etc., involved in the summer recharge operation. To store heat efficiently, it is common to use large arrays of boreholes drilled in square, hexagonal, or cylindrical array shapes (Figure 5), at distances of a few metres (3-7 $\mathrm{m}$ are typical) such that, as demonstrated above, the heat storage fields of each borehole overlap and are intercepted efficiently by adjacent boreholes. It is, moreover, important that the overall array volume is as "closed" as possible, meaning that the array's surface-areato-volume ratio is minimised. Thus, a long line of 36 boreholes will not be efficient at storing heat, as each borehole will be exposed on two sides to unexploited rock, through which heat can conduct away. A square array of $6 \times 6$ boreholes (dimension $30 \mathrm{~m} \times 30 \mathrm{~m}$, if boreholes spaced at $6 \mathrm{~m}$ ) will be far more efficient at storing heat. The perimeter of the square array, through which heat can be lost to unexploited rock, is only $120 \mathrm{~m}$, compared with $420 \mathrm{~m}$ for the linear array (spaced at $6 \mathrm{~m}$ ).

Figure 6 compares the performance of a $6 \times 6$ array of $36 \times 100 \mathrm{~m}$ deep boreholes, spaced at $6 \mathrm{~m}$, with heat extraction and rejection loads comparable to those in Figures 1-3 above (i.e., $36 \times 9000 \mathrm{kWh}=324 \mathrm{MWh}$ ), evenly distributed over a 4-month heat rejection season ("summer") and a 4month heat extraction season ("winter") separated by a 2month nonoperational period. The borehole constructions are also identical to those described for Figures 2 and 3 (above), and the scenario is simulated in the software Earth Energy Designer (EED) version 3 [49].

Figure 6(a) plots four scenarios: 


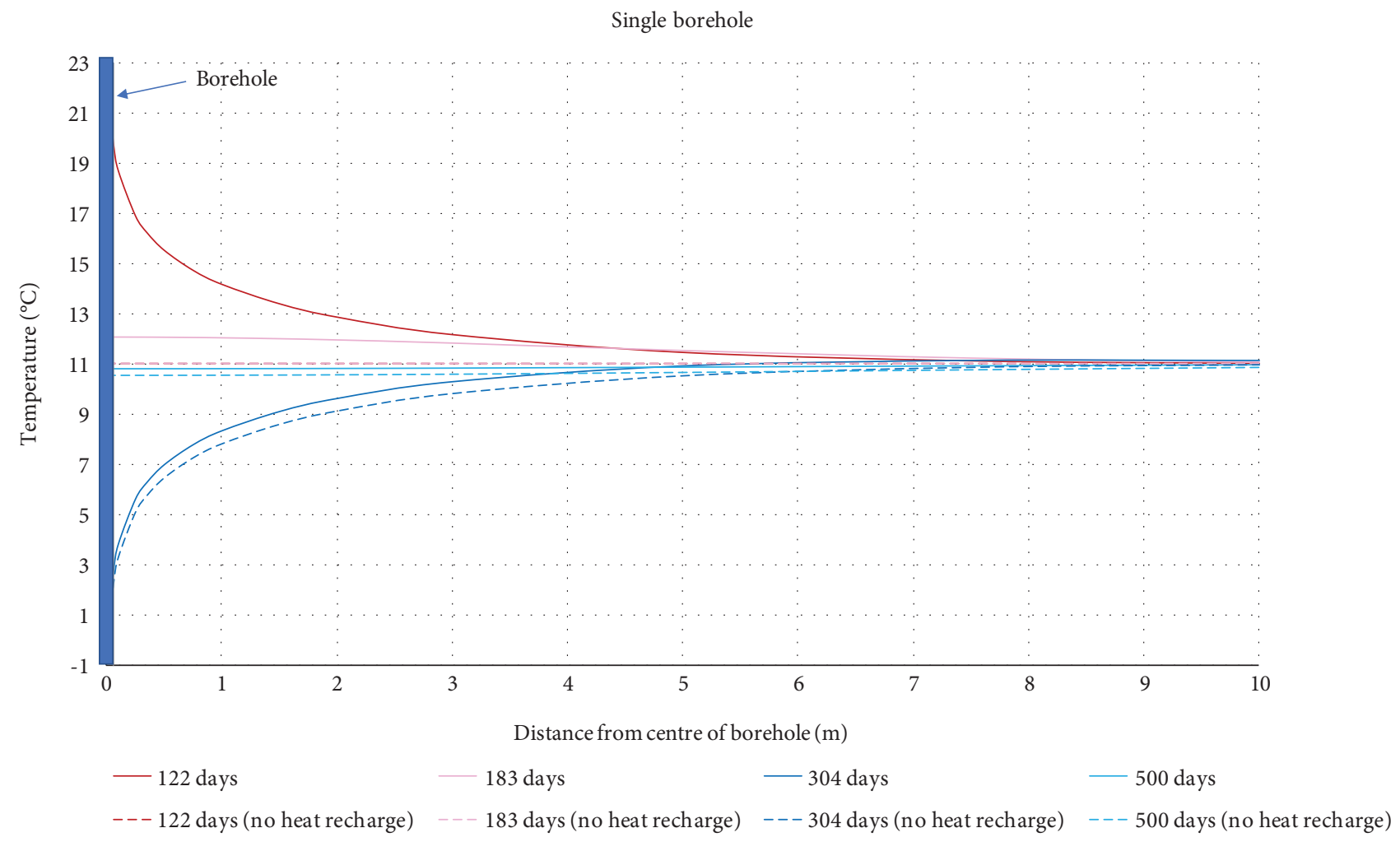

FIGURE 3: Calculated temperature in the rock mass at varying radial distances and selected specified times, for the heat injection/abstraction scenario (scenario 1) and the heat extraction only scenario (scenario 2) specified in the text.

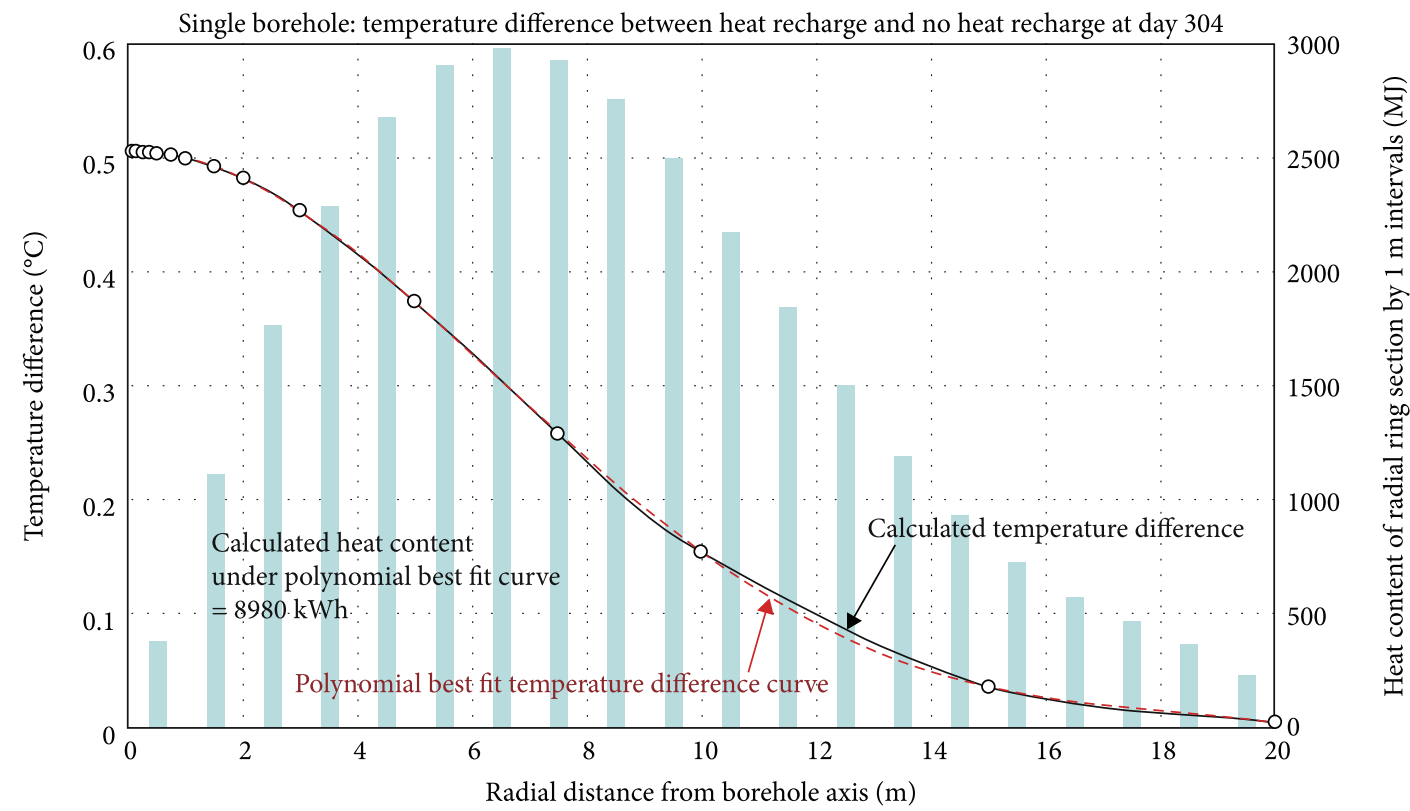

Figure 4: Calculated difference in temperature (black line) between scenario 1 (with heat recharge) and scenario 2 (without heat recharge) at end of the heat extraction period $(t=304$ days), together with best-fit polynomial approximation to the curve (red dashed line). The total difference in stored heat is calculated by integrating the polynomial with respect to radial volume between 0.06 and $20 \mathrm{~m}$ and is estimated as almost $9000 \mathrm{kWh}$ (which it should theoretically be). The distribution of this stored heat with radial distance is shown in the background histogram bars by $1 \mathrm{~m}$ radial slices. The histogram suggests that the bulk of the stored heat is at radial distances of 3 to $10 \mathrm{~m}$ from the borehole (peak at 6-7 m). The polynomial best fit curve has an equation $y=-1.313 E-05 x^{4}+6.418 E-04 x^{3}-9.067 E-03 x^{2}+$ $4.663 E-03 x+5.046 E-01$. 


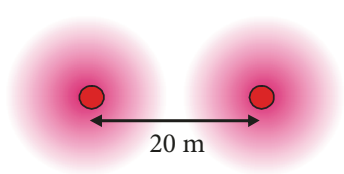

(a)

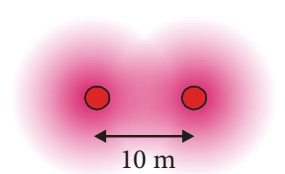

(b)

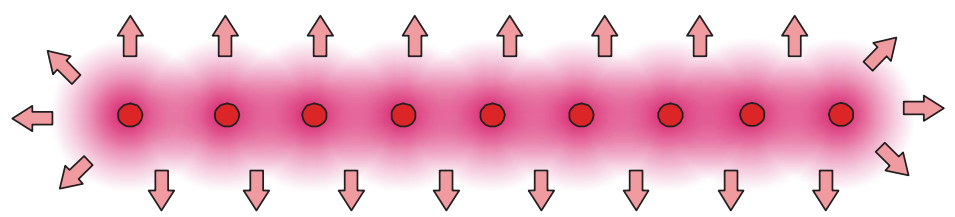

(c)
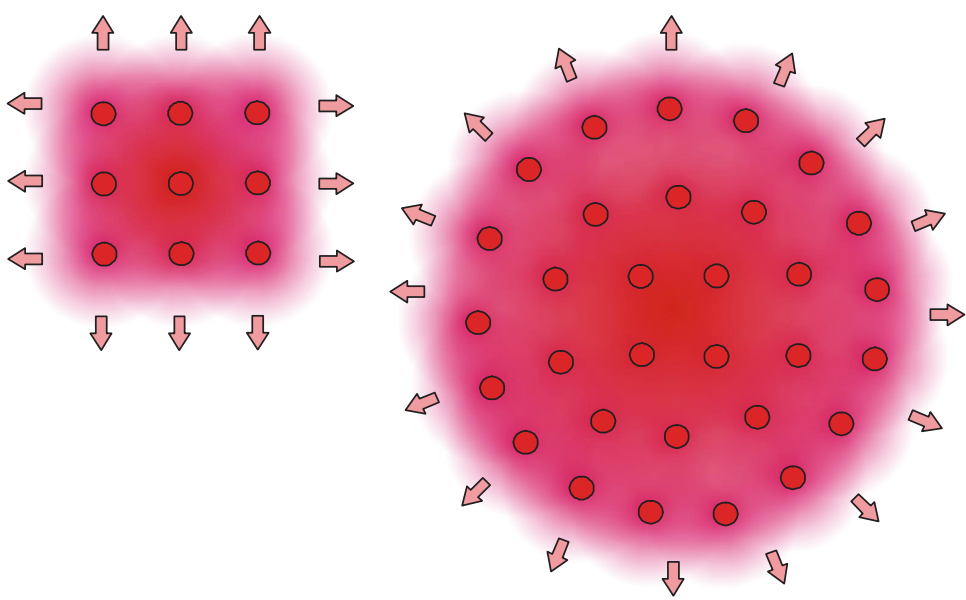

(d)

(e)

FIGURE 5: Different array shapes for BTES thermal energy storage. (a) Two BHE spaced $>20 \mathrm{~m}$ apart will typically not thermally interfere with each other; (b) if the spacing is $<10 \mathrm{~m}$, however, thermal interference can become significant (depending on thermal energy loadings). (c) A linear array of closely spaced BHE will not be especially efficient at storing heat, due to the large perimeter through which heat can be lost. (d) A more "closed" array shape, such as a square grid of BHE, will be more efficient at storing heat, although (e) larger hexagonal or cylindrical arrays will be even more efficient, due to the declining ratio of surface area to volume as array size increases.

(i) A balanced heat rejection/extraction scenario for the 36 boreholes, with heat loads of $324 \mathrm{MWh}$ per annum. The maximum summer and minimum winter average heat transfer fluid temperatures are plotted, and these are typically around $+22^{\circ} \mathrm{C}$ and just below $0^{\circ} \mathrm{C}$, respectively (and hence fully compatible with Figure 2)

(ii) A "heat rejection only" scenario for the 36 boreholes, with a heat rejection of $324 \mathrm{MWh}$ per annum, spread over 4 months. The temperatures climb rapidly year on year, with a maximum summer heat transfer fluid temperature of around $+36^{\circ} \mathrm{C}$ in year 15 and $+38.6^{\circ} \mathrm{C}$ in year 25

(iii) A "heat extraction only" scenario for the 36 boreholes, with a heat out-take of $324 \mathrm{MWh}$ per annum, spread over 4 months. The temperatures drop rapidly year on year, with a minimum winter heat transfer fluid temperature of around $-14^{\circ} \mathrm{C}$ in year 15 and $-16.6^{\circ} \mathrm{C}$ in year 25 . It should here be noted that these temperatures are far lower than would be experienced in real GSHC schemes-at such temperatures, the ground and heat transfer fluid would freeze, latent heat of freezing would be released, and geotechnical (frost heave, or U-tube compression) issues might be experienced. As EED does not consider latent heat of freezing, these scenarios can only be considered "hypothetical" and representative of sensible heat balance

(iv) The plot also shows the summer maximum and winter minimum temperatures for a single borehole in "rejection only" and "extraction only" modes

Although the single borehole curves do show a year-onyear trend (as noted above), the trend is very shallow compared with the 36-borehole array "rejection only" and "extraction only" curves, immediately demonstrating that the 36-borehole array is far more efficient at "accumulating" or storing heat and "coolth" than the single borehole. Indeed, while in the 36-borehole "extraction only" scenario, the fluid temperature reaches just below $-2^{\circ} \mathrm{C}$ in the first winter; in the heat "storage" scenario, one could extract $400 \mathrm{kWh}$ (following the rejection of $324 \mathrm{kWh}$ ) to bring the temperature down to $-2^{\circ} \mathrm{C}$. This additional $76 \mathrm{MWh}$ represents a first-year 


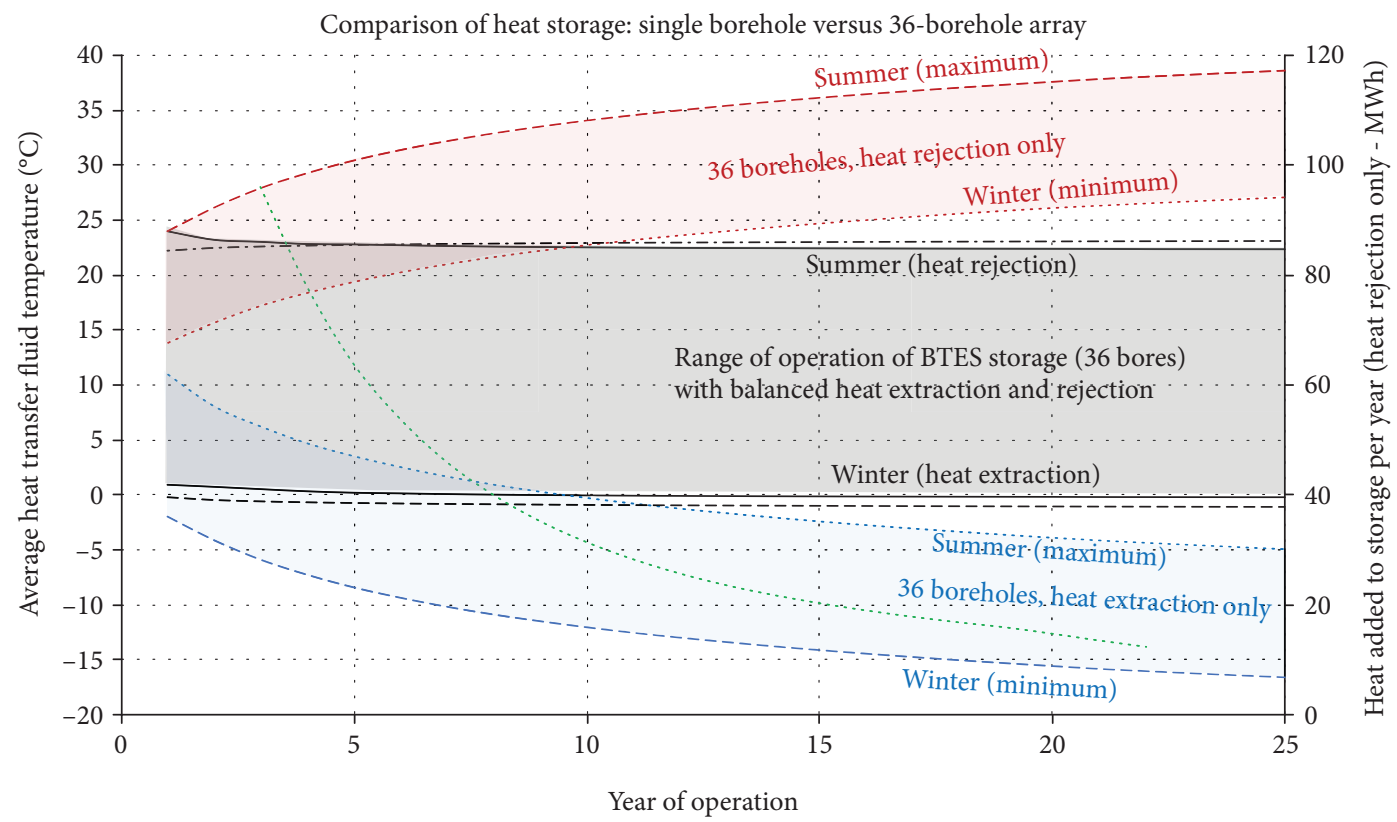

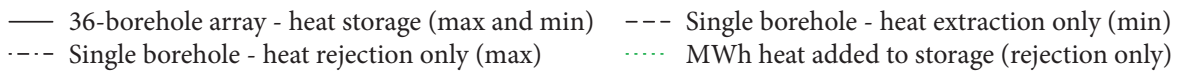

(a)

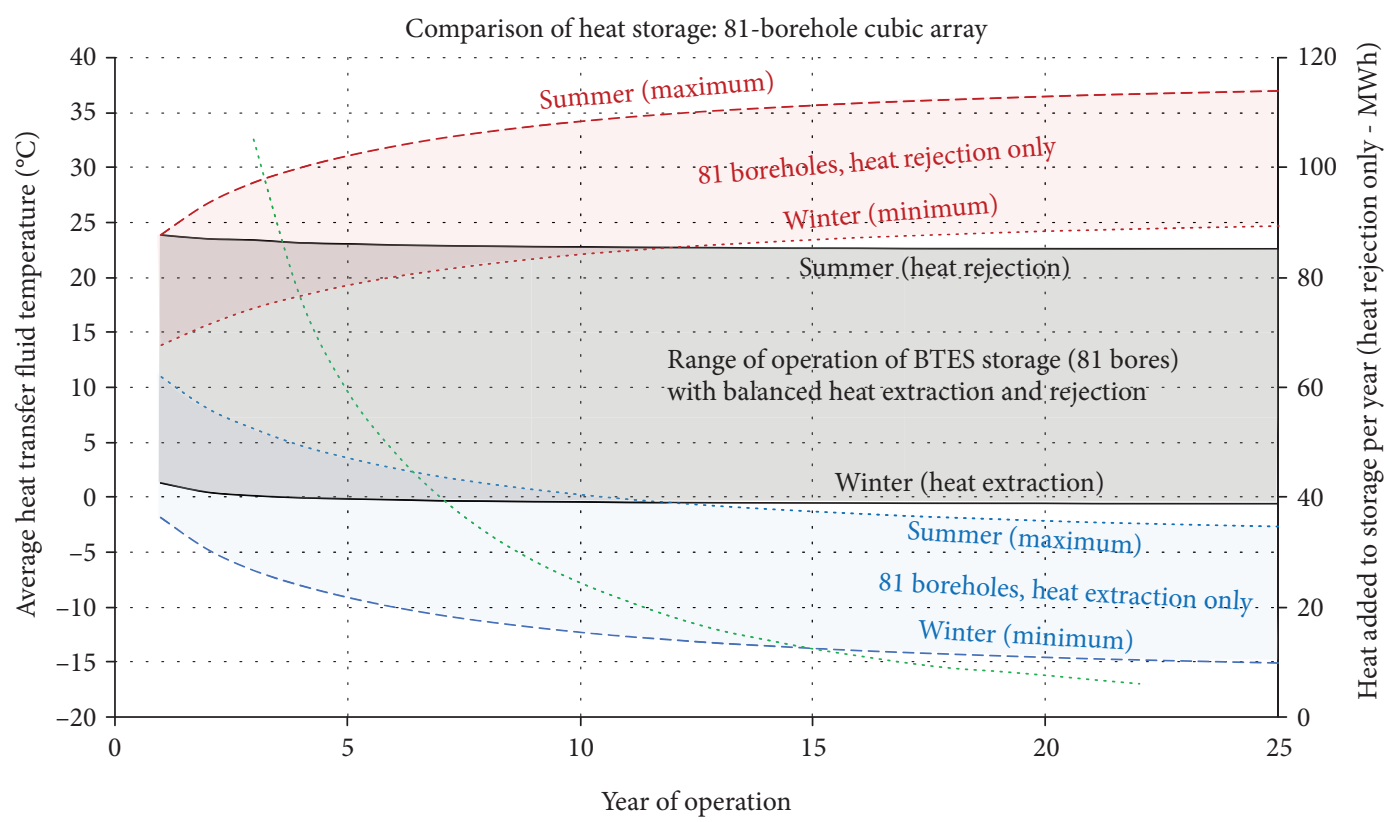

81-borehole array - heat storage (max and $\min )$ MWh heat added to storage (rejection only)

(b)

FIGURE 6: Average heat transfer fluid temperatures in a BHE array. The grey envelope in the middle of the diagram shows the range of heat transfer fluid temperature for a BTES where heat extraction and rejection are seasonally balanced (324 MWh/season, each across a 4-month extraction and rejection season). The envelope between the red dotted lines indicates the typical heat transfer fluid temperature range for a BTES where heat is being rejected year on year (324 MWh/season; maximum temperature in summer, minimum in winter); the envelope between the blue dotted lines indicates the range of heat transfer fluid temperature for a BTES where heat is being extracted year on year (324 MWh/season). In both diagrams, the green dotted line shows the estimated annual marginal heat accumulation in the BHE storage in the case of heat rejection only (calculated from the gradient of the heat rejection temperature curve, a rock volumetric heat capacity of $2.4 \mathrm{MJ} / \mathrm{m}^{3} / \mathrm{K}$, and a BTES volume of $90,000 \mathrm{~m}^{3}$ ). (a) An array of 36 number, $100 \mathrm{~m}$ deep boreholes on a $6 \times 6$ square grid at $6 \mathrm{~m}$ spacing; (b) an array of 81 number, $44.4 \mathrm{~m}$ deep boreholes on a $9 \times 9$ square grid at $5.6 \mathrm{~m}$ spacing. (a) also shows the temperature curve for a comparable single $100 \mathrm{~m}$ deep borehole extracting or rejecting $9 \mathrm{MWh}$ heat per 4-month season (i.e., 324 MWh/36). Initial ambient average ground temperature $=11^{\circ} \mathrm{C}$. 
thermal recovery advantage of $23 \%$ (compare with $5.6 \%$ for the single borehole).

\section{Effect of Array Geometry}

One could argue that the $6 \times 6$ array of 36 boreholes is still an inefficient shape in terms of heat storage, as the depth $(100 \mathrm{~m})$ is still far greater than the lateral dimension $(30 \mathrm{~m})$. The volume of the array is thus $90,000 \mathrm{~m}^{3}$, and the surface area $13,800 \mathrm{~m}^{2}$, giving a surface area-to-volume ratio of $0.153 \mathrm{~m}^{-1}$. By designing the array as a more evenly dimensioned shape (lateral dimension approximately equal to depth), the surface area/volume ratio could be reduced to $0.124 \mathrm{~m}^{-1}$ for a cylinder of radius $24 \mathrm{~m}$ and depth $49 \mathrm{~m}$ or to $0.134 \mathrm{~m}^{-1}$ for a cubic configuration of depth and width $\mathrm{c}$. $45 \mathrm{~m}$ (all have volume $90,000 \mathrm{~m}^{2}$ ). Figure 7 plots the surface area-to-volume ratio, versus volume for a variety of bulk BTES shapes. A spherical shape is effectively impossible to achieve in the context of a BTES array comprising linear boreholes. The next most efficient common array shape is a cylindrical array, where the depth is equal to the diameter. In this context, it can be noted that the Canadian Drake Landing scheme comprises a cylindrical array of 144 boreholes, spaced at $2.25 \mathrm{~m}$ and drilled to $37 \mathrm{~m}$ deep. The array has a diameter of around $35 \mathrm{~m}$, approximately equal to depth, thus minimising surface area-to-volume ratio [20].

To test the effect of array geometry, the Earth Energy Designer simulation (Figure 6(a)) has been rerun for the same heat loads, but applied to an array comprising a cubic array of 81 boreholes, $44.4 \mathrm{~m}$ deep on a $9 \times 9$ grid, spaced at $5.6 \mathrm{~m}$ ( $44.8 \mathrm{~m}$ array width), giving a total drilled length of $3596 \mathrm{~m}$, an array volume of $89,100 \mathrm{~m}^{3}$ (almost identical to the array simulated in Figure 6(a)), and an array surface area of $11,970 \mathrm{~m}^{2}$. This gives a significantly reduced surface areato-volume ratio of $0.134 \mathrm{~m}^{-1}$. The results of the simulation are plotted in Figure 6(b) and are superficially rather similar to Figure 6(a). The main difference is

(i) that, in the early years, the temperature gradient of the "heat rejection only" curve is steeper than Figure 6(a), representing heat accumulation rates of 80-100 MWh/a (thermal accumulation efficiency of 25-30\%).

(ii) In later years, however, the rate of temperature and heat accumulation flattens out (thermal accumulation efficiency of $<10 \%)$ to a greater degree than Figure 6(a)

The first observation is as one would expect: the lower surface area-to-volume ratio of the cubic array leads to more efficient accumulation of heat. The second observation suggests that not all forms of array surface area are equal and that the ground-surface interface (which is much larger in Figure 5(b): $2007 \mathrm{~m}^{2}$ for the $9 \times 9$ array, as opposed to $900 \mathrm{~m}^{2}$ for the $6 \times 6$ array) is particularly effective at losing heat. Indeed, in Earth Energy Designer [49], while the rock mass is simulated as an infinite conductive medium, the ground surface is effectively simulated as a constant temperature (Dirichlet) boundary condition. Thus, depending on the time perspective of thermal energy storage, modelling suggests that particular attention should be paid to the ground surface above the BTES array and that, in some cases, it may be desirable to minimise the area of the surface footprint through which heat can be lost, or to insulate the surface footprint. Some authors [33] explicitly recommend insulating the ground surface above the BTES array and, in this case, identify a cylindrical array, where the depth is equal to the radius, as the most thermally efficient solution (in terms of surface area-to-volume ratio, provided that the upper thermal insulation is "ideal"). This solution is also shown in Figure 7 as "Cylinder (depth = radius) top surface insulated." Indeed, the BTES system at Neckarsulm in SW Germany $[22,33]$ closely approaches an idealised geometry and the top surface of the BTES is insulated with a $20 \mathrm{~cm}$ layer of extruded polystyrene and then backfilled to a depth of 3-4 m [23]. The top surface of the BTES at Emmaboda, Sweden, is insulated by $0.4 \mathrm{~m}$ of foam glass [30].

\section{Effect of Borehole Spacing}

As a final experiment in the Earth Energy Designer [49] modelling environment, another BTES of $90,000 \mathrm{~m}^{3}$ has been simulated, but this time with 289 boreholes $(17 \times 17$ grid) to $44.4 \mathrm{~m}$ spaced at $2.8 \mathrm{~m}$. The BTES thus has the same overall dimension as Figure 5(b), but the borehole spacing has been halved and the number of boreholes (and total drilled metres) has been increased by a factor of 3.56. Applying exactly the same heat extraction and rejection loads as Figures 6(a) and 6(b) (324 MWh per 4-month heat extraction or rejection season) results in the temperature evolution curves shown in Figure 8. The average heat transfer per metre of borehole has thus dropped from $30.8 \mathrm{~W} \mathrm{~m}^{-1}$ to $8.6 \mathrm{~W} \mathrm{~m}^{-1}$.

It will be noted, in the case of heat rejection only, that the temperature of the BTES increases (Figure 8) at almost the same rate as in Figure 6(b): i.e., the dotted green line has an almost identical trajectory, with around $100 \mathrm{MWh}$ of heat being added per year in the early years and $<10 \mathrm{MWh}$ per year being added after year 20. The main difference is that, because the heat loads are being distributed across larger numbers of boreholes, the heat transfer fluid temperatures in each borehole are far less extreme than in Figure 6(b). In the case with balanced rejection and abstraction, the operating temperatures are just over $+5^{\circ} \mathrm{C}$ in the winter and around $+16^{\circ} \mathrm{C}$ in the summer (compare with $-0.5^{\circ} \mathrm{C}$ and $+23^{\circ} \mathrm{C}$, respectively, in the case of Figure 5(b)). This will result in a very significant difference in the efficiency of operation of any heat pump and may even permit the use of free cooling (as opposed to compressor-powered cooling) in the summer. The importance of achieving a thermal balance between heat rejection and extraction is well recognised: actually achieving this balance in real large buildings, whose needs are often dominated by cooling, is considerably more difficult. Various ways have been considered [50] of utilising excess rejected heat directed towards Haukeland Hospital's GSHC system (165 boreholes on a $5 \times 33$ grid spaced at $6 \mathrm{~m}$ ) in Bergen. In other words, decreasing the borehole spacing from, say, $6 \mathrm{~m}$ to $3 \mathrm{~m}$, does not make any great difference to the total storage 


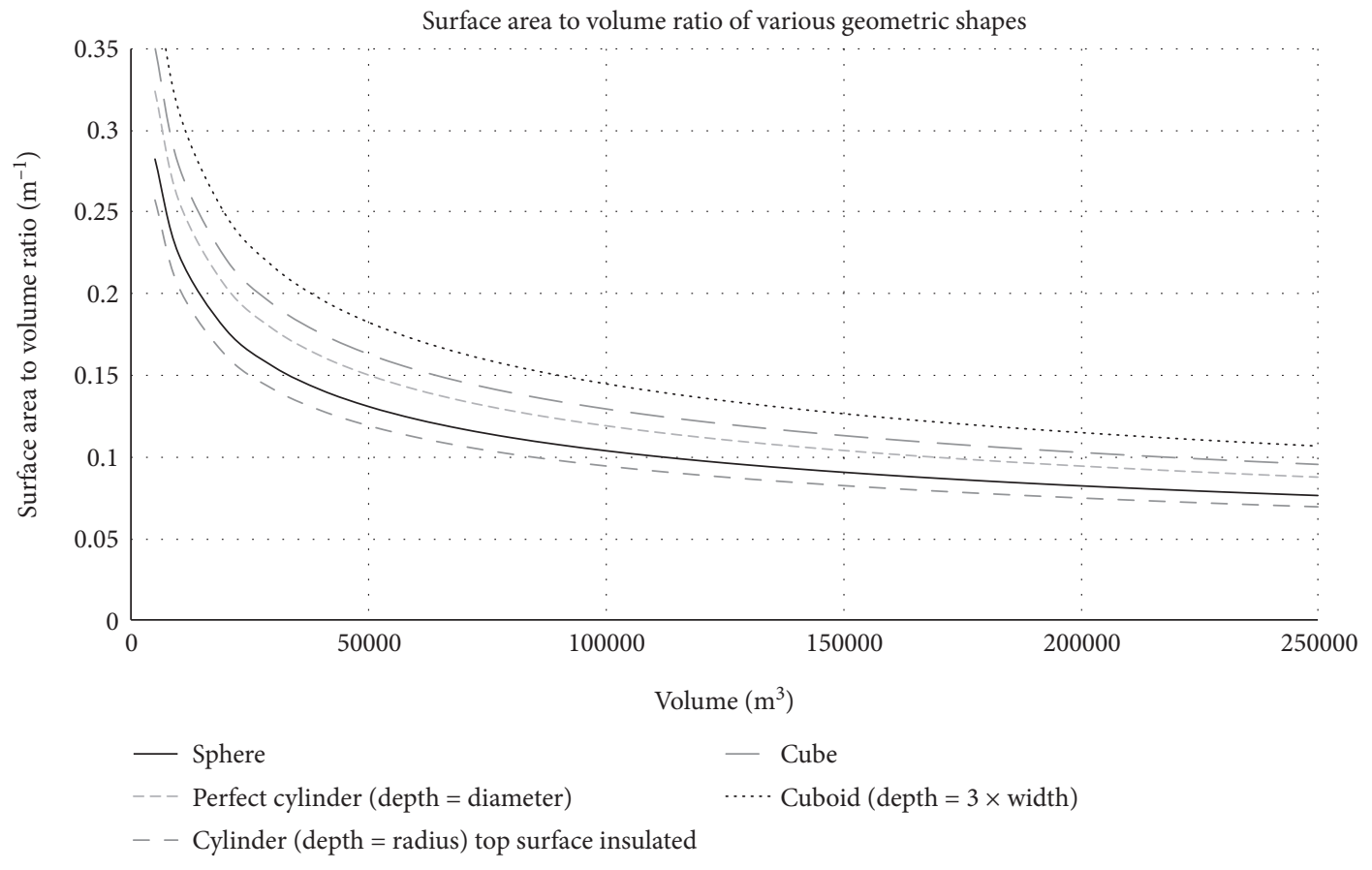

FIGURE 7: Surface area-to-volume ratio of various geometric shapes as a function of volume.

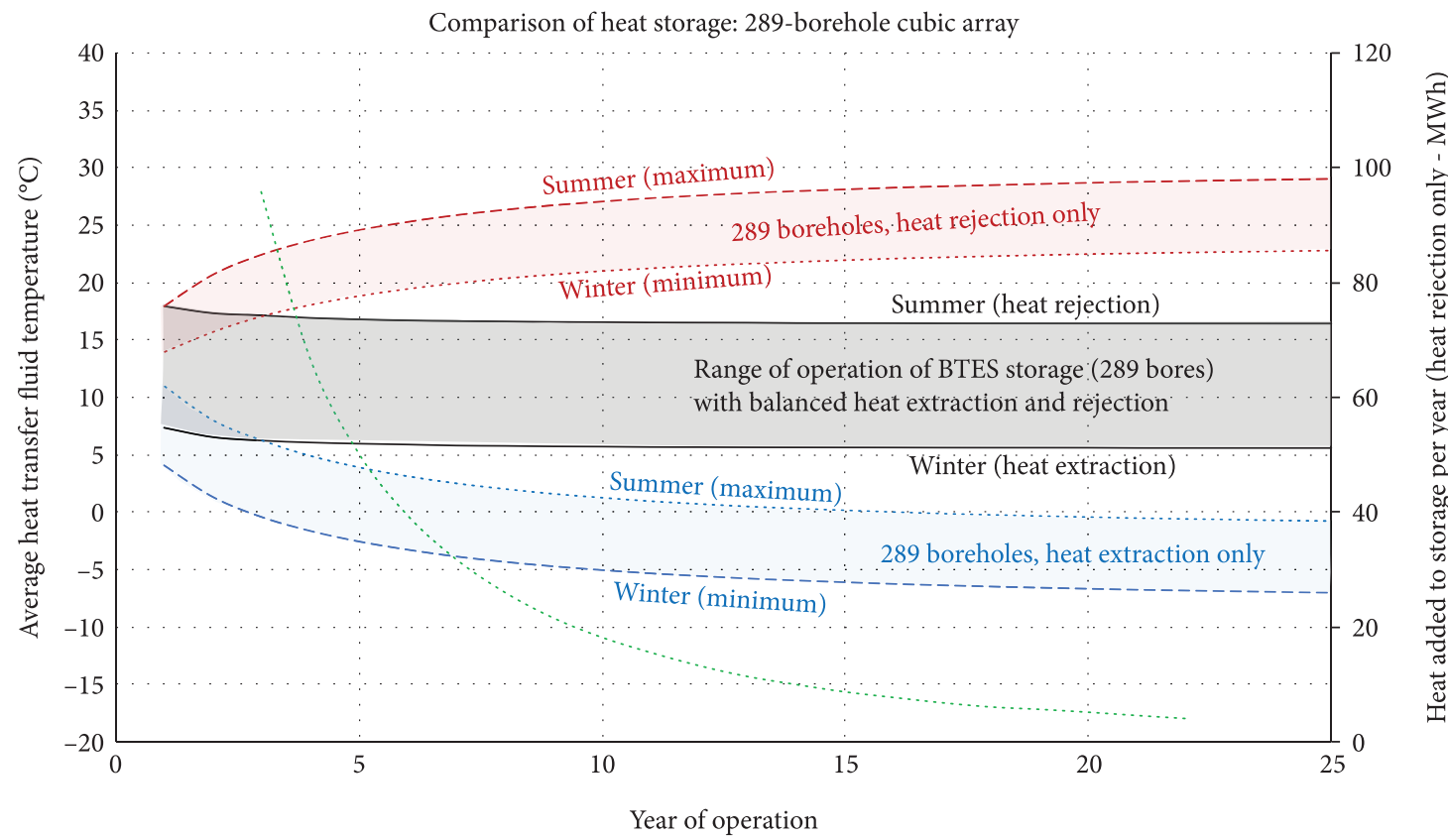

FIGURE 8: The maximum (summer) and minimum (winter) average heat transfer fluid temperatures in a BHE array, in cases where a balanced heat extraction and heat rejection ( $324 \mathrm{MWh} /$ season, each across a 4-month extraction and rejection season) is applied, compared with the same system where heat rejection only (324 MWh/season) and where heat extraction only (324 MWh/season) are practised. The BTES is an array of 289 number, $44.4 \mathrm{~m}$ deep boreholes on a $17 \times 17$ square grid at $2.8 \mathrm{~m}$ spacing (i.e., the same BTES volume as Figure 5 (b), but with half the borehole spacing). The green dotted line shows the estimated annual marginal heat accumulation in the BHE storage in the case of heat rejection only (calculated from the gradient of the heat rejection temperature curve, a rock volumetric heat capacity of $2.4 \mathrm{MJ} / \mathrm{m}^{3} / \mathrm{K}$, and a BTES volume of $90,000 \mathrm{~m}^{3}$ ). Initial ambient average ground temperature $=11^{\circ} \mathrm{C}$. 
efficiency of the BTES (all other things, including overall BTES dimension) being equal, but it has a significant impact on how efficiently that thermal storage can be accessed.

Amongst the forest of BTES theory, it is important to remember practical considerations. One major factor, when drilling closely spaced boreholes, is to remember that boreholes are not always vertical. Indeed, the quick and cheap drilling method (down the hole hammer drilling) favoured by many BHE practitioners can result in very substantial deviations. At Emmaboda, Sweden [30], the deviation of 21 (randomly selected) boreholes of the total of 140 boreholes in the granodiorite rock was measured. At $150 \mathrm{~m}$ depth, the horizontal "drift" of borehole trajectory varied from $4 \mathrm{~m}$ to $26 \mathrm{~m}$, with an average of $16 \mathrm{~m}$ (i.e., over $1 \mathrm{~m}$ horizontal drift for every $10 \mathrm{~m}$ drilled). Thus, if one drills on a tidy rectangular grid at $4 \mathrm{~m}$ spacing, one must realise that the true situation at depth may be very different, and there is always the risk of drilling through an adjacent borehole.

\section{High-Temperature Heat Storage by BTES}

As we have already noted, in many larger BTES schemes, heat is not stored around the ambient ground temperature, but rather at high temperatures characteristic of waste heat from industrial, combustion, or incineration processes. The general principles of borehole spacing and array geometry discussed above apply to high-temperature BTES arrays. However, determining the efficiency of heat storage is somewhat simpler.

In such schemes, the first few years of BTES operation are typically dedicated to "charging up" the BTES with surplus heat, with little or no extraction. As the temperature within the BTES increases, the rate of heat loss to the surrounding rocks also increases and eventually a steady-state heat loss $\left(Q_{\mathrm{sS}}\right)$ is approached where the bulk temperature of the BTES ceases to increase sharply (this can be observed in the "heat rejection only" curves of Figures 6(a) and 6(b)). It is commonly claimed in the literature [51] that the recovery efficiency of a BTES increases over the first year of operation (the transient phase) as the rock volume in and around the BTES increases towards an operational temperature. As the rock around the BTES begins to warm up, relative conductive heat losses from the BTES decrease. However, an "honest" account of storage efficiency should ideally recognise the quantities of heat that have had to be "dispersed" into the surrounding rock mass to achieve this effect. For example, it is claimed that the "BTES efficiency" of the Canadian Drake Landing BTES scheme increased from $9 \%$ to $40 \%$ over the first four years of operation [19].

At steady state, cyclical seasonal storage and extraction can commence. The amount of heat charged to the BTES store will typically exceed the amount of heat discharged by a quantity $Q_{s s}$ over an annual cycle, thus ensuring that the average temperature of the BTES is maintained. In this case, the thermal recovery factor $\left(\eta_{\mathrm{e}}\right)$ is defined [17] as

$$
\eta_{\mathrm{e}}=\frac{\text { Heat extracted over an annual cycle }}{\text { Heat recharged over an annual cycle }} \text {. }
$$

To achieve a high thermal recovery factor, the steadystate heat loss (which is a function of temperature, BTES geometry, rock thermal conductivity, and insulation) should be as low as possible, while the seasonal transfer should be as high as possible. Hellström [17] argues that heat transfer in a BTES can be analysed in terms of three components:

(i) An initial transient thermal build-up of the temperature field around the BTES

(ii) A steady-state heat loss $\left(Q_{\mathrm{ss}}\right)$ from the BTES

(iii) A superimposed periodic variation on an annual (or other) cycle. In idealised analysis, this may be approximated as a sinusoidal function

Hellström [17] provides an idealised case study where the heat recharged to a BTES at any given time $Q(t)$ is equal to the sum of $Q_{s s}$ and a sinusoidal storage recharge and recovery component of amplitude $Q_{1}$.

$$
Q(t)=Q_{\mathrm{ss}}+Q_{1} e^{i \varphi} e^{2 \pi t / t_{p}}
$$

where $\varphi$ is a phase lag and $t_{\mathrm{p}}$ is the period of the rechargedischarge cycle (typically annual, but potentially diurnal). It is possible to demonstrate [17] that, to achieve a recovery factor $\left(\eta_{\mathrm{e}}\right)>30 \%$, then $Q_{1} / Q_{\mathrm{ss}}$ should exceed 3.7. To achieve greater $>50 \%$ requires $Q_{1} / Q_{s s}$ to exceed 4.5 . To put these figures into perspective, analytical methods are also published $[16,17]$ for estimating $Q_{s s}$ for a range of cylindrical and rectangular BTES geometries (Table 1). Using these methods, we can estimate that, for a $50^{\circ} \mathrm{C}$ heat store in a cylindrical topinsulated BTES of radius $60 \mathrm{~m}$ and depth $60 \mathrm{~m}$, in a granite of thermal conductivity $2.2 \mathrm{~W} \mathrm{~m}^{-1} \mathrm{~K}^{-1}$, one might expect a steady-state heat loss $Q_{\mathrm{ss}}$ of over $130 \mathrm{~kW}$. This in turn implies, that to get a thermal recovery factor of over $30 \%$, we require a peak discharge rate of over $0.5 \mathrm{MW}$ of heat.

It is noteworthy that, even in the Neckarsulm BTES system, which is regarded [33] as approaching an ideal geometry, thermal losses were relatively high, with only $20 \%$ of the charged solar heat (187 of $979 \mathrm{MWh}$ ) being usefully recovered [22]. It may seem that commonly cited seasonal thermal storage efficiencies of $20-40 \%$ would not be especially attractive. The new Swedish Emmaboda BTES, operating at temperatures over $40^{\circ} \mathrm{C}$, is believed to be on target to achieve a thermal recovery factor of over 60\% [30], however. The attractiveness of such an approach depends, however, on the value that is placed on surplus summer heat. In reality, this is often very low, to the extent that, in most major cities in temperate and southern Europe, surplus heat is regarded as a waste product and considerable sums are spent on disposing of it.

Nordell [3] has also analysed the optimisation of BTES design, in terms of geometry, borehole spacing, shape, etc., taking into account thermal physical factors, construction factors, and economic considerations. Amongst his findings are the following: 
TABLE 1: Calculated steady-state heat losses from a cylindrical BTES array, with a temperature at the edge of the store of $50^{\circ} \mathrm{C}$, an ambient undisturbed average rock temperature of $12^{\circ} \mathrm{C}$, a rock thermal conductivity of $2.2 \mathrm{~W} \mathrm{~m}^{-1} \mathrm{~K}^{-1}$, and a rock volumetric heat capacity of $2.2 \mathrm{MJ} \mathrm{m}^{-3} \mathrm{~K}^{-1}$ with expanded polystyrene insulation (thermal conductivity $0.04 \mathrm{~W} \mathrm{~m}^{-1} \mathrm{~K}^{-1}$ ) of thickness $0.5 \mathrm{~m}$ extending over the top of the BTES and to a depth $D_{\mathrm{i}}$ down the sides, using the mathematical technique of [17].

\begin{tabular}{|c|c|c|c|c|c|c|c|c|}
\hline \multirow{2}{*}{ Radius } & \multirow{2}{*}{ Depth } & \multirow{2}{*}{$D_{\mathrm{i}}$} & \multicolumn{4}{|c|}{ Heat losses $Q_{\mathrm{ss}}$} & \multirow{2}{*}{ BTES heat capacity } & \multirow{2}{*}{ Heat capacity/Q $Q_{s s}$} \\
\hline & & & Insulated top & Insulated sides & Uninsulated portion & Total & & \\
\hline $\mathrm{m}$ & $\mathrm{m}$ & $\mathrm{m}$ & $\mathrm{kW}$ & $\mathrm{kW}$ & $\mathrm{kW}$ & $\mathbf{k W}$ & MWh K ${ }^{-1}$ & $\mathrm{MWh} \mathrm{K}^{-1} \mathrm{~kW}^{-1}$ \\
\hline 20 & 60 & 6 & 3.8 & 1.1 & 38.8 & 43.8 & 46.1 & 1.1 \\
\hline 30 & 60 & 6 & 8.6 & 1.7 & 53.2 & 63.5 & 103.7 & 1.6 \\
\hline 45 & 60 & 6 & 19.3 & 2.6 & 74.3 & 96.2 & 233.3 & 2.4 \\
\hline 60 & 60 & 6 & 34.4 & 3.4 & 95.5 & 133.3 & 414.7 & 3.1 \\
\hline 80 & 60 & 6 & 61.1 & 4.6 & 123.7 & 189.4 & 737.2 & 3.9 \\
\hline 20 & 60 & 12 & 3.8 & 2.3 & 34.1 & 40.2 & 46.1 & 1.1 \\
\hline 30 & 60 & 12 & 8.6 & 3.4 & 46.2 & 58.2 & 103.7 & 1.8 \\
\hline 45 & 60 & 12 & 19.3 & 5.2 & 63.8 & 88.3 & 233.3 & 2.6 \\
\hline 60 & 60 & 12 & 34.4 & 6.9 & 81.5 & 122.8 & 414.7 & 3.4 \\
\hline 80 & 60 & 12 & 61.1 & 9.2 & 105.1 & 175.4 & 737.2 & 4.2 \\
\hline 20 & 100 & 6 & 3.8 & 1.1 & 48.9 & 53.9 & 76.8 & 1.4 \\
\hline 30 & 100 & 6 & 8.6 & 1.7 & 65.0 & 75.3 & 172.8 & 2.3 \\
\hline 45 & 100 & 6 & 19.3 & 2.6 & 89.1 & 111.0 & 388.8 & 3.5 \\
\hline 60 & 100 & 6 & 34.4 & 3.4 & 112.9 & 150.8 & 691.2 & 4.6 \\
\hline 80 & 100 & 6 & 61.1 & 4.6 & 144.6 & 210.3 & 1228.7 & 5.8 \\
\hline
\end{tabular}

(i) The greater the borehole thermal resistance, the greater the optimum number of boreholes and the closer their spacing

(ii) The greater the rock thermal conductivity, the greater the borehole spacing and the fewer boreholes required

(iii) The bigger the store, the relatively smaller the heat loss. For an optimised BTES in a given set of Swedish conditions, the thermal recovery factor (theoretically) exceeds $50 \%$ for a heat extraction capacity of $1 \mathrm{GWh} /$ year

\section{Free Convection within the BHE Water Column}

It has already been noted that the $\mathrm{BHE}$ itself often comprises one (or sometimes two) U-tubes of pipe installed down the length of the borehole. The borehole itself is typically between 100 and $150 \mathrm{~mm}$ diameter. In incompletely lithified rocks or sediments, or where the water table is relatively deep, the borehole is commonly backfilled with a thermally enhanced grout, often based either on a mixture of bentonite (to give low hydraulic conductivity) and fine silica sand (to give high thermal conductivity) or a thermally efficient cement mix. In situations where the rock is hard and lithified and where the water table is high (due to the rock's low permeability and/or to high rainfall), the borehole is left open and allowed to fill with natural groundwater. In this case, the groundwater provides the thermal contact between the BHE U-tube(s) and the walls of the borehole (Figure 9).
It has been shown that convection cells can start to occur in a fluid-filled vertical tube (borehole) when the temperature gradient along the length of the borehole exceeds a certain threshold [52-56]:

$$
\text { Critical gradient }\left({ }^{\circ} \mathrm{C} \mathrm{m}^{-1}\right)=\frac{g \beta \theta}{c_{\mathrm{p}}}+\frac{\mathrm{Ra}_{\text {crit }} \alpha v}{g \beta r^{4}} \text {, }
$$

where $g$ is the acceleration due to gravity $\left(9.81 \mathrm{~m} \mathrm{~s}^{-2}\right), \beta$ is the fluid's isobaric thermal expansion coefficient $\left(\mathrm{K}^{-1}\right), \theta$ is the absolute temperature $(\mathrm{K}), c_{\mathrm{p}}$ is the fluid heat capacity at constant pressure $\left(\mathrm{J} \mathrm{kg}^{-1} \mathrm{~K}^{-1}\right), \mathrm{Ra}_{\text {crit }}$ is the critical Rayleigh number (which may be between 69 and 216, depending on the thermal conductivity of the borehole wall), $\alpha$ is the fluid's thermal diffusivity $\left(\mathrm{m}^{2} \mathrm{~s}^{-1}\right), v$ is the kinematic viscosity $\left(\mathrm{m}^{2} \mathrm{~s}^{-1}\right)$, and $r$ is the bore radius $(\mathrm{m})$. The Rayleigh number is a dimensionless number for a fluid, indicating a tendency towards buoyancy-driven or convective flow.

The implication of this equation is that only small temperature gradients are needed to initiate convection in fluid-filled boreholes, e.g., in boreholes as narrow as $50 \mathrm{~mm}$ with axial temperature gradients as low as $0.03^{\circ} \mathrm{C} \mathrm{m}^{-1}[52$, 57]-i.e., natural geothermal gradients.

Thus, the application of a heating or cooling load to a polyethylene U-tube within a water-filled borehole can be assumed to be sufficient to initiate free convection in the groundwater column. This, in turn, enhances the heat transfer between the U-tube and the borehole wall. Water has a rather low thermal conductivity of $0.6 \mathrm{~W} \mathrm{~m}^{-1} \mathrm{~K}^{-1}$. Thus, a borehole filled with static water would be expected to exhibit a very high borehole thermal resistance $\left(R_{\mathrm{b}}\right.$ - see equation 


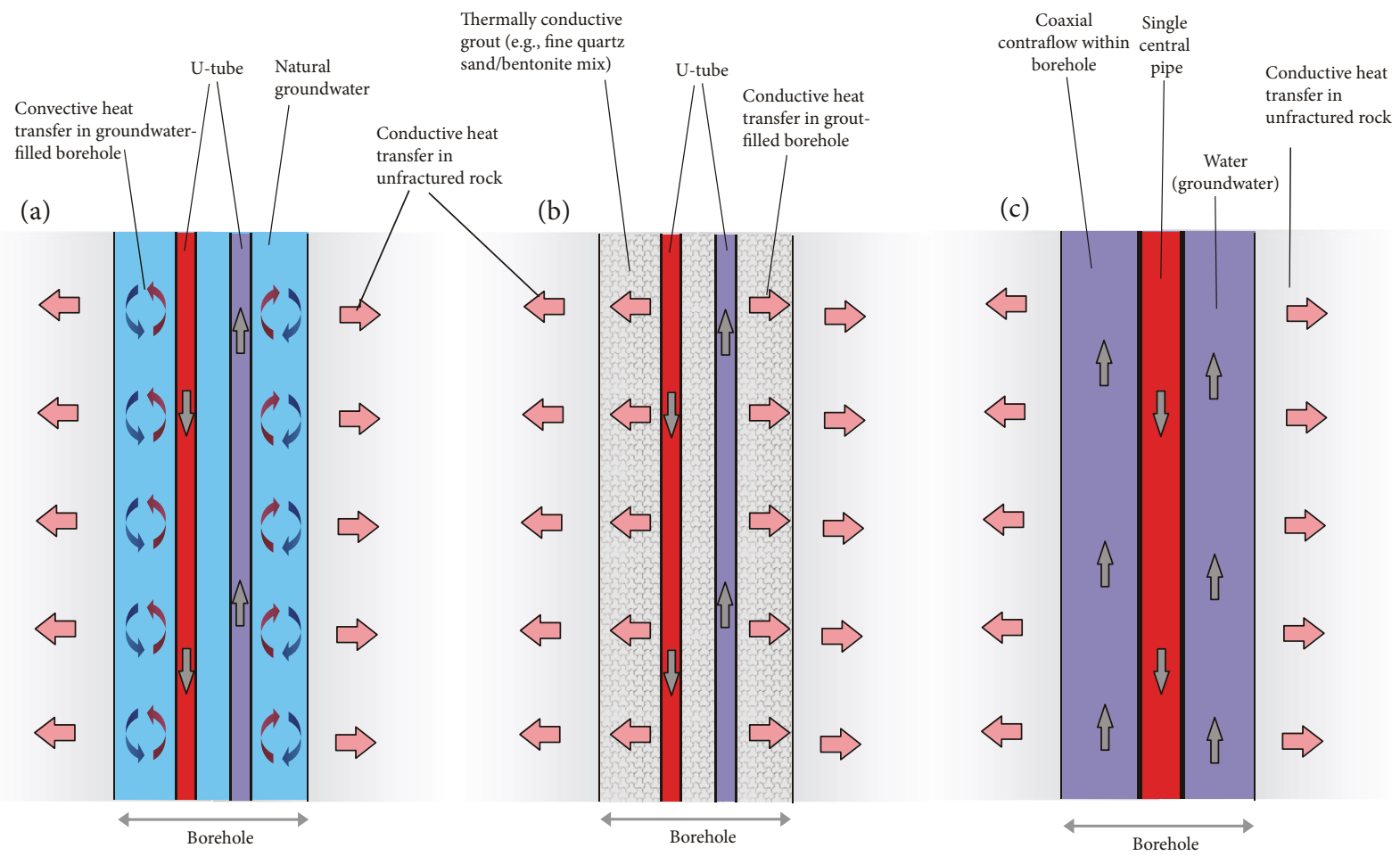

Figure 9: (a) A groundwater-filled BHE in unfractured rock, where heat transfer from the two warm shanks (upflow and downflow) of a $\mathrm{U}$-shaped heat exchange pipe to the borehole wall is facilitated by thermally driven convection; (b) a BHE backfilled with grout and where conduction is the main heat transfer mechanism; a coaxial open borehole heat exchange arrangement.

TABLE 2: Results of thermal response tests carried out in groundwater-filled boreholes in the basalt rock sequences of the Faroe Islands, after [58]. *Artesian flow from borehole plugged during test.

\begin{tabular}{lcccccc}
\hline & $\begin{array}{c}\text { Casing } \\
\text { depth }(\mathrm{m})\end{array}$ & $\begin{array}{c}\text { Casing OD } \\
(\mathrm{mm})\end{array}$ & $\begin{array}{c}\text { Borehole } \\
\text { depth }(\mathrm{m})\end{array}$ & $\begin{array}{c}\text { Borehole diameter } \\
(\mathrm{mm})\end{array}$ & $\begin{array}{c}R_{\mathrm{b}} \text { from TRT } \\
\left(\mathrm{K} \mathrm{m} \mathrm{W}^{-1}\right)\end{array}$ & $\begin{array}{c}\text { Projected } R_{\mathrm{b}} \text { during heat } \\
\text { extraction }\left(\mathrm{K} \mathrm{m} \mathrm{W}^{-1}\right)\end{array}$ \\
\hline Petur Egholm, Torshavn & 6 & 168 & 150 & 140 & 0.066 & 0.065 \\
Jarðfeingi, Torshavn & 9 & 168 & 200 & 140 & 0.08 & 0.10 \\
Petur Hammer, Tvøroyri & 6 & 168 & 200 & 140 & 0.07 & 0.095 \\
\hline
\end{tabular}

(3)). In practice, this is not the case, and we can infer that thermally driven convection is occurring within the water column. To illustrate the importance of convection as a mechanism for heat transfer within a BHE, SWECO carried out thermal response tests (TRT) in several individual groundwater-filled BHEs installed in the basalt rocks of the Faroe Islands [58]. The results are summarised in Table 2.

Very low borehole thermal resistances $\left(R_{\mathrm{b}}\right)$ of 0.066 to $0.08 \mathrm{~km} \mathrm{~W}^{-1}$ were obtained. The program Earth Energy Designer [49] can be used to simulate the theoretical $R_{\mathrm{b}}$, for a $140 \mathrm{~mm}$ borehole, installed with a $40 \mathrm{~mm}$ single U-tube at a shank spacing of $70 \mathrm{~mm}$. A $25 \%$ ethanol heat transfer fluid has been assumed, with a flow rate designed to give a transient-turbulent Reynolds number of c. 2500. If the borehole was assumed to be filled with static water (thermal conductivity $0.6 \mathrm{~W} \mathrm{~m} \mathrm{~K}^{-1}$ ), resistances $R_{\mathrm{b}}$ of around $0.2 \mathrm{~km} \mathrm{~W}^{-1}$ are calculated, over twice that actually observed. If the borehole is assumed to be filled with a thermally enhanced grout with a conductivity of $1.7 \mathrm{~W} \mathrm{~m}^{-1} \mathrm{~K}^{-1}$, resistances $R_{\mathrm{b}}$ of around $0.11 \mathrm{~km} \mathrm{~W}^{-1}$ are calculated. Thus, free convection in a groundwater-filled borehole is demonstrated to be more thermally efficient than a borehole filled with a thermally conductive grout of thermal conductivity $1.7 \mathrm{~W} \mathrm{~m} \mathrm{~K} \mathrm{~K}^{-1}$.

Moreover, the greater the temperature contrast between the heat transfer fluid and the borehole walls, the greater the convective heat transfer effect. This is evidenced by a decrease in the $R_{\mathrm{b}}$ with increasing heat injection rates, from thermal response tests in an $80 \mathrm{~m}$ groundwater-filled $\mathrm{BHE}$ in crystalline, poorly fractured igneous bedrock at Göteborg, Sweden ( $110 \mathrm{~mm}$ bore, single $40 \mathrm{~mm}$ OD polyethylene Utube [59]). With a heat injection rate of $28 \mathrm{~W} \mathrm{~m}^{-1}$, the borehole thermal resistance was estimated as $0.089 \mathrm{~km} \mathrm{~W}^{-1}$. At heat injection rates of 55,70 , and $142 \mathrm{~W} \mathrm{~m}^{-1}, R_{\mathrm{b}}$ fell to $0.069,0.068$, and $0.051 \mathrm{~km} \mathrm{~W}^{-1}$, respectively [60]. As the rock in this test borehole was poorly fractured, the thermally driven convective effects are believed to be restricted to the 
borehole itself, rather than to a "thermosiphon" (see below) effect in the surrounding rock.

In order to minimise borehole thermal resistance, several BTES systems have omitted the U-tube altogether (Figure 9(c)). At Emmaboda [29], a BHE design has been developed using a single pipe coaxially mounted in a water-filled borehole. The pipe is insulated by a concentric layer of stagnant water. In operation, the heat transfer fluid is circulated down the pipe and up the annulus between the pipe and the borehole walls. To avoid fluid loss, the walls must be either cased or comprise essentially impermeable fracture-free hard rock. Testing at Emmaboda suggested $R_{\mathrm{b}}$ values as low as $0.02 \mathrm{~km} \mathrm{~W}^{-1}$.

\section{Forced Convection through a BHE Array}

For BHEs whose objective is solely to extract heat from the ground (e.g., for space heating) or to reject heat to the ground (e.g., for space cooling or industrial cooling), flow of groundwater past the BHE is generally regarded as a positive factor. This is because the flow of groundwater carries with it a "cargo" of environmental heat that can replenish heat that has been extracted from the ground or remove heat from the BHE and surrounding ground in the case of heat rejection. This stabilises ground temperatures, preventing them from reaching extreme values that would result in poor heat pump performance. In the case where groundwater flow is driven by regional topographically determined head gradients, the concomitant heat transport with the flowing water is termed forced convection or advection. The presence of regional groundwater advection implies that a "plume" of heat (or "coolth," if heat extraction is being practiced) extends downgradient away from the BHE and increases the opportunity for downgradient thermal interference. Significant flow of groundwater in a geological stratum (or aquifer) requires two preconditions:

(i) That the aquifer has sufficient hydraulic conductivity $(K)$ to permit water to percolate. Hydraulic conductivity is simply the permeability of the rock mass with respect to water

(ii) That there is a sufficient groundwater head gradient $(i)$ to drive groundwater flow ( $i$ is dimensionless). The ultimate source of groundwater head gradient is usually different in topographic elevation (although other mechanisms, such as overpressurisation of sedimentary basins, can result in head gradients)

The groundwater flux (which is commonly also termed the Darcy velocity or Darcy flux $\left.\left(v_{\mathrm{D}}\right)\right)$ in $\mathrm{m}^{3}$ per $\mathrm{m}^{2}$ cross section per day (i.e., $\mathrm{m} \mathrm{d}^{-1}$ ) is given by Darcy's law (assuming flow is laminar):

$$
v_{\mathrm{D}}=-K \cdot i,
$$

where $K=$ hydraulic conductivity in $\mathrm{m} \mathrm{d}^{-1}$. In the case of a BHE operating in a permeable rock or sediment mass with flowing groundwater, the temperature of the heat transfer fluid within, and of the rock around, the BHE will initially change (increase in the case of heat rejection, decrease in the case of heat extraction) in accordance with the line source heat (equation (2) or (3)). Over time, however, the temperature will then tend to stabilise and will eventually reach a steady-state temperature $\left(\theta_{\mathrm{s}}\right)$. At any point $(x, y)$ in a Cartesian coordinate system, where groundwater flows in the $+x$ direction, the following equation can be derived [61, 62], based on equations for a moving line source of heat $[63,64]$ :

$$
\theta_{s}(x, y)-\theta_{0}=\frac{q}{2 \pi \lambda} \exp \left(\frac{v_{\text {the }} x}{2 \alpha}\right) K_{0}\left(\frac{v_{\text {the }} r}{2 \alpha}\right),
$$

where the thermal velocity $\left(v_{\text {the }}\right)$ is related to the Darcy velocity (flux) $\left(v_{\mathrm{D}}\right)[62]$ :

$$
v_{\text {the }}=\frac{v_{\mathrm{D}} c_{V \text { wat }}}{c_{V}} .
$$

(i) $\mathcal{c}_{\mathrm{V}}$ is the bulk volumetric heat capacity of the saturated aquifer and $c_{\mathrm{V}_{\text {wat }}}$ is the volumetric heat capacity of water (c. $\left.4.19 \mathrm{MJ} \mathrm{m}^{-3} \mathrm{~K}^{-1}\right)$

(ii) $r=$ radial distance from heat source $=\sqrt{x^{2}+y^{2}}(\mathrm{~m})$

(iii) $K_{0}$ is the zero-order modified Bessel function of the second kind

It is found [62] that, for typical aquifer scenarios, the impact of groundwater flow on BHE performance becomes significant at Darcy fluxes of around $0.01 \mathrm{~m} \mathrm{~d}^{-1}$ (previous evaluations [65] approximately concur with this finding), while at Darcy fluxes of around $1 \mathrm{~m} \mathrm{~d}^{-1}$, the groundwater flux was sufficient to effectively maintain the BHE at close to ambient ground temperatures. Van Meurs [15] also concluded that heat losses from an underground thermal store became significant at a Darcy flux in excess of $0.05 \mathrm{~m} \mathrm{~d}^{-1}\left(5 \times 10^{-7} \mathrm{~m} \mathrm{~s}^{-1}\right.$ cited in [3]). It is also possible to demonstrate [62] that the greater the Darcy flux, the more rapidly the thermal effects of the flux are seen (i.e., a deviation of heat transfer fluid temperature towards a steady state): for a Darcy flux $>0.1 \mathrm{~m} \mathrm{~d}^{-1}$, some form of steady state should become apparent within a time frame of less than 3 days.

On the other hand, for a BTES scheme, where the objective is to build up a seasonal reserve of heat or "coolth," groundwater flow is generally regarded as a negative factor, as it will tend to "wash away" the accumulated heat down the hydraulic gradient. As a general rule of thumb, it seems reasonable to suppose that, if the thermal transport velocity is large compared with the dimension of the BTES array, the effect of groundwater flow would be significant. For example, let us consider a BTES array of width $40 \mathrm{~m}$, within an aquifer of bulk volumetric heat capacity $\left(c_{\mathrm{V}}\right) 2.4 \mathrm{MJ} \mathrm{m}^{-3} \mathrm{~K}^{-1}$. The calculations given in Table 3 apply: it will be seen that, if the Darcy flux exceeds c. $1 \mathrm{~cm} \mathrm{~d}^{-1}$ (equivalent to a hydraulic conductivity of $1 \times$ $10^{-5} \mathrm{~m} \mathrm{~s}^{-1}-\mathrm{a}$ fine sand or similar-coupled with a 
TABLE 3: Thermal velocities and equivalent thermal travel distances for a range of Darcy fluxes (and equivalent hydraulic conductivities, given a groundwater head gradient of 0.01 ). For reference, hydraulic conductivities of $10^{-2}$ to $10^{-4} \mathrm{~m} \mathrm{~s}^{-1}$ are typical of sands, $10^{-5}$ to $10^{-7} \mathrm{~m} \mathrm{~s}^{-1}$ are typical of rather fine sands, silts, and loams. A bulk volumetric heat capacity of $2.4 \mathrm{MJ} \mathrm{m}^{-3} \mathrm{~K}^{-1}$ is assumed for the aquifer.

\begin{tabular}{|c|c|c|c|c|c|c|}
\hline $\begin{array}{l}\text { Hydraulic conductivity with } \\
\text { head gradient }=0.01\end{array}$ & $\begin{array}{l}\text { Darcy } \\
\text { flux }\end{array}$ & $\begin{array}{l}\text { Hydraulic velocity } \\
\text { if } n_{\mathrm{e}}=1 \%\end{array}$ & $\begin{array}{l}\text { Hydraulic velocity } \\
\text { if } n_{\mathrm{e}}=20 \%\end{array}$ & $\begin{array}{l}\text { Thermal } \\
\text { velocity }\end{array}$ & $\begin{array}{l}\text { Heat travel distance } \\
\text { in } 6 \text { months }\end{array}$ & $\begin{array}{c}\text { Heat travel } \\
\text { distance in } 1 \text { year }\end{array}$ \\
\hline $\mathrm{ms}^{-1}$ & $\mathrm{~m} \mathrm{~d}^{-1}$ & $\mathrm{~m} \mathrm{~d}^{-1}$ & $\mathrm{~m} \mathrm{~d}^{-1}$ & $\mathrm{~m} \mathrm{~d}^{-1}$ & $\mathrm{~m}$ & $\mathrm{~m}$ \\
\hline $1.16 E-07$ & 0.0001 & 0.01 & 0.0005 & 0.0002 & 0.0 & 0.1 \\
\hline $5.79 E-07$ & 0.0005 & 0.05 & 0.0025 & 0.0009 & 0.2 & 0.3 \\
\hline $1.16 E-06$ & 0.001 & 0.1 & 0.005 & 0.0017 & 0.3 & 0.6 \\
\hline $5.79 E-06$ & 0.005 & 0.5 & 0.025 & 0.0087 & 1.6 & 3.2 \\
\hline $1.16 E-05$ & 0.01 & 1 & 0.05 & 0.0175 & 3.2 & 6.4 \\
\hline $5.79 E-05$ & 0.05 & 5 & 0.25 & 0.0873 & 15.9 & 31.9 \\
\hline $1.16 E-04$ & 0.1 & 10 & 0.5 & 0.17 & 31.9 & 63.7 \\
\hline $5.79 E-04$ & 0.5 & 50 & 2.5 & 0.87 & 159 & 319 \\
\hline $1.16 E-03$ & 1 & 100 & 5 & 1.75 & 319 & 637 \\
\hline $5.79 E-03$ & 5 & 500 & 25 & 8.73 & 1593 & 3186 \\
\hline $1.16 E-02$ & 10 & 1000 & 50 & 17.5 & 3186 & 6372 \\
\hline
\end{tabular}

hydraulic head gradient of 1 in 100), heat can migrate several metres per year, which begins to be significant in terms of the size of the BTES array.

Application of equation (8) rapidly becomes a complex procedure when applied to BTES arrays comprising multiple boreholes. Moreover, the third dimension (upward and downward heat loss) rapidly becomes important when simulating BTES arrays. Therefore, three-dimensional coupled heat and groundwater transport numerical models (often finite element, such as FEFLOW [66]) are typically applied to simulate the effects of groundwater flow on the operation of a BTES array. A word of warning is appropriate: equations (8) and (9) assume intimate thermal contact and rapid thermal equilibration between the flowing groundwater and the aquifer mineral matrix. In other words, it assumes either a porous medium (silt, sand, and gravel) or a fractured/fissured rock with a relatively dense fracture network. If the aquifer is a fractured rock, where the hydraulic conductivity is dominated by a few conductive fractures, then equation (9) does not apply and the thermal velocity more closely approaches the hydraulic velocity (see Table 3 ). If the effective porosity $\left(n_{\mathrm{e}}\right)$ is low (typically $<1 \%$ in fractured rock aquifers), the rate of heat migration can be very high. Most modelling techniques also make the assumptions implicit in equation (9) unless fracture flow is explicitly simulated within the modelling environment.

Where heat losses via groundwater flow are restricted to a limited number of horizons or highly permeable fractures, these can be excluded by extending casing down the borehole, or they can be grouted during drilling. Both the procedures significantly increase drilling costs. In Sweden, drilling with casing costs 3-4 times as much as drilling open hole in hard rock [30].

\section{Free Convection in a BTES Store}

The very act of heating or cooling a single BHE or an array of BHEs can induce convective transfer of heat, not just within the borehole itself, but within the surrounding rock or sediment (provided it is permeable). As has been seen above, for BHEs being solely used for extraction or rejection of heat, this additional convective heat exchange with the rock or sediment mass will often be beneficial. However, for a BTES aiming at seasonal heat storage, significant convective heat losses to a wider volume of rock or sediment effectively mean that heat or "coolth" is being lost from the store

Let us imagine an $80 \mathrm{~m}$ deep BHE, with a heat exchange pipe installed within an open borehole, completely filled with groundwater to the surface. A length of steel casing protrudes $0.5 \mathrm{~m}$ above the surface (Figure 10-in reality of course, a typical Scandinavian borehole would be completed below ground with a watertight well-head). Let us imagine that the water temperature within the borehole is initially at $10^{\circ} \mathrm{C}$. Furthermore, suppose that we reject heat to the borehole such that the column of groundwater in the borehole is heated by $4^{\circ} \mathrm{C}$.

Figure 11(a) shows the well-known dependence of water density on temperature. The density of water is at a maximum at $\mathrm{c} .+4^{\circ} \mathrm{C}$. Above $+4^{\circ} \mathrm{C}$, the density decreases and the rate of density decrease increases as temperature increases. Thus, in our hypothetical borehole, initially at $10^{\circ} \mathrm{C}$, an increase in temperature to $14^{\circ} \mathrm{C}$ will result in a density decrease from 999.70 to $999.24 \mathrm{~kg} \mathrm{~m}^{-3}$. The column of groundwater, initially $80 \mathrm{~m}$ high, will now have a height of $80.036 \mathrm{~m}$ (an excess height of $3.6 \mathrm{~cm}$ ). If the temperature rise is $10^{\circ} \mathrm{C}$, the new density (at $20^{\circ} \mathrm{C}$ ) will be $998.20 \mathrm{~kg} \mathrm{~m}^{-3}$ and the excess height will be $12 \mathrm{~cm}$ (Figure 10(b)). In the latter case, if the steel casing is suddenly removed, the excess height of water of $12 \mathrm{~cm}$ will run away at the surface and the water pressure at the base of the borehole will now be $(80 \mathrm{~m} \times$ $\left.9.81 \mathrm{~m} \mathrm{~s}^{-2} \times 998.20 \mathrm{~kg} \mathrm{~m}^{-3}\right)=783.4 \mathrm{kPa}$, rather than the original $\left(80 \mathrm{~m} \times 9.81 \mathrm{~m} \mathrm{~s}^{-2} \times 999.70 \mathrm{~kg} \mathrm{~m}^{-3}\right)=784.6 \mathrm{kPa}$.

If there is a hydraulically conductive fracture at the base of the borehole, groundwater will enter the borehole due to 


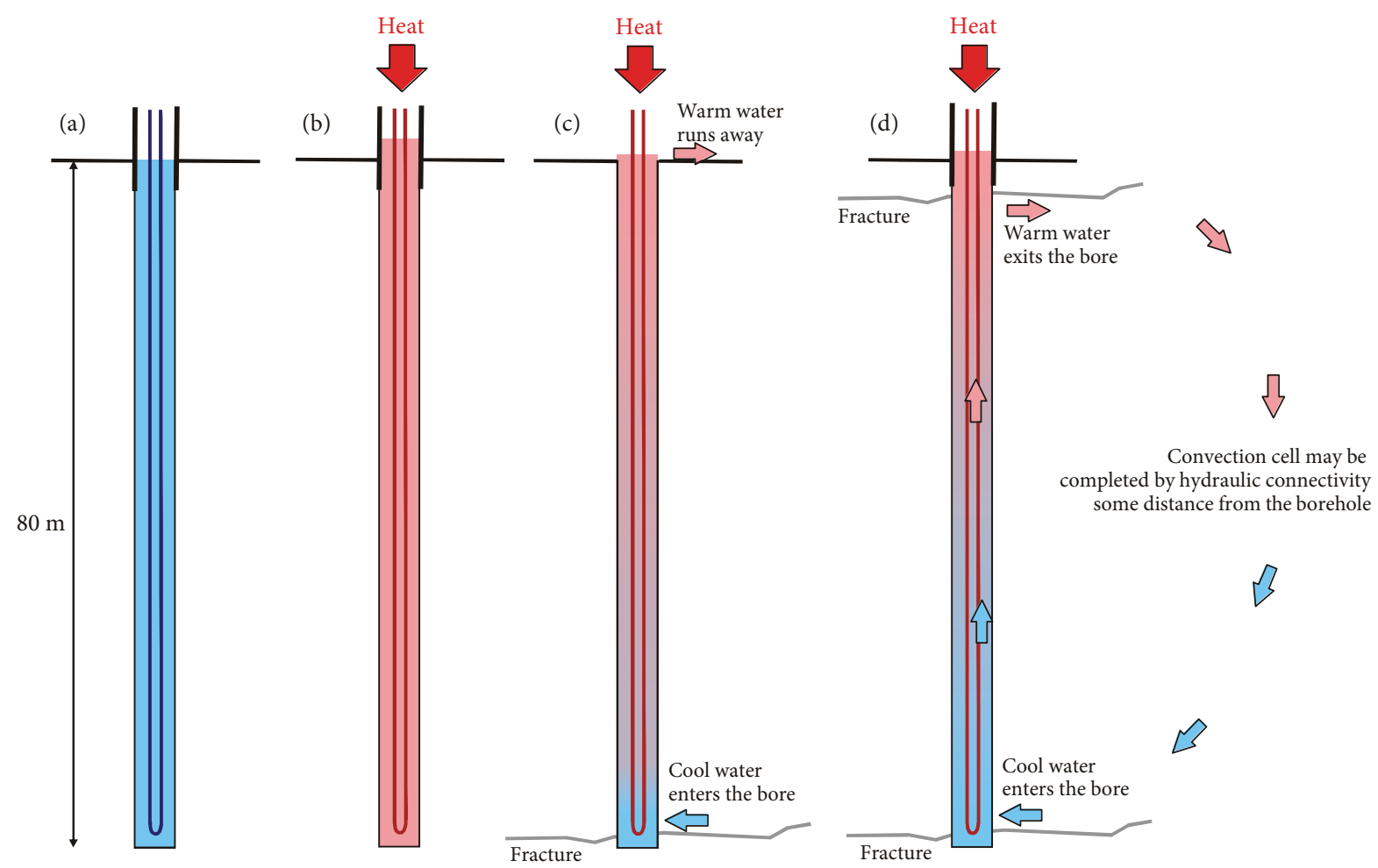

Figure 10: (a) A groundwater-filled, $80 \mathrm{~m}$ deep BHE in unfractured rock, with a length of surface casing protruding above ground level; the groundwater level is at the surface. (b) If heat is rejected to the BHE, the groundwater heats up and expands, rising into the surface casing. (c) If the casing is removed, the excess water runs away at the surface; if a hydraulically conductive fracture exists at depth in the borehole, cool water will be drawn into the borehole due to the reduced heat and will subsequently expand, creating a thermally driven groundwater flow up the borehole (a "thermosiphon" or thermal pump). (d) If a fracture exists at a higher level in the borehole, the warm groundwater can flow away via that fracture, creating a convection cell within the surrounding rock or sediment mass, with the borehole as a central convecting axis.

the pressure difference of c. $1.12 \mathrm{kPa}$ between the aquifer and the borehole, and an equivalent amount of water will run away at the surface. As the "new" water is heated by the BHE, a convection-driven thermal "pump" will develop, with groundwater entering at the base of the borehole and running away at the surface (Figure 10(c)).

It should be possible to see that, if there is also a shallow hydraulically conductive fracture, $1 \mathrm{~m}$ below ground level, there is no need for surface overflow to produce a convection-driven system, whereas the initial pressure of water at the end of the fracture was equivalent to $(1 \mathrm{~m} \times$ $\left.9.81 \mathrm{~m} \mathrm{~s}^{-2} \times 999.70 \mathrm{mg} \mathrm{m}^{-3}\right)=9807 \mathrm{kPa}$, the pressure after heating by $20^{\circ} \mathrm{C}$ will be $\left(1.12 \mathrm{~m} \times 9.81 \mathrm{~m} \mathrm{~s}^{-2} \times 998.20 \mathrm{~kg}\right.$ $\left.\mathrm{m}^{-3}\right)=10.967 \mathrm{kPa}$. The excess pressure (c. $1.2 \mathrm{kPa}$ ) will thus force water into the fracture from the borehole, also removing heat (as warm water) from the borehole environment. Because of the loss of water from the top of the borehole, new cool water will be drawn into the borehole by the opposite pressure differential at the base of the borehole and free convection will have been initiated. If the upper and lower fractures are somehow hydraulically interconnected via a broader fracture network, then a convection cell will result (Figure 10(d)). If the fractures are not interconnected, the free convection will reduce after some time as excess head builds up in the upper fracture system, opposing the convective energy.

By extrapolating this thought experiment still further, it should be easy to see that in any given borehole, the components of a fracture network intersecting an open BHE above the borehole's (admittedly somewhat loosely defined) "hydraulic centre" will lose water upon heating, and those below will gain fresh cool groundwater from the aquifer. By extending this further to an ever finer and denser network of fractures, it will be seen that such a BHE-driven convection cell could develop in an open borehole even in an ideal porous medium aquifer. This effect is wellknown and is termed the "thermosiphon effect" [69-73].

One would expect that the practice of grouting a BHE borehole, using a grout with high thermal conductivity (to promote efficient heat exchange) but low hydraulic conductivity, would significantly reduce the likelihood of a thermosiphon effect developing, because the open borehole forms the main axis for thermally driven convective flow. Similarly, the practice of lining a BHE borehole with a casing extending throughout any permeable rock horizons (or to the base of the borehole) would also be effective at suppressing the thermosiphon effect. Theoretically, however, with a permeable enough rock matrix outside the borehole and with a high 


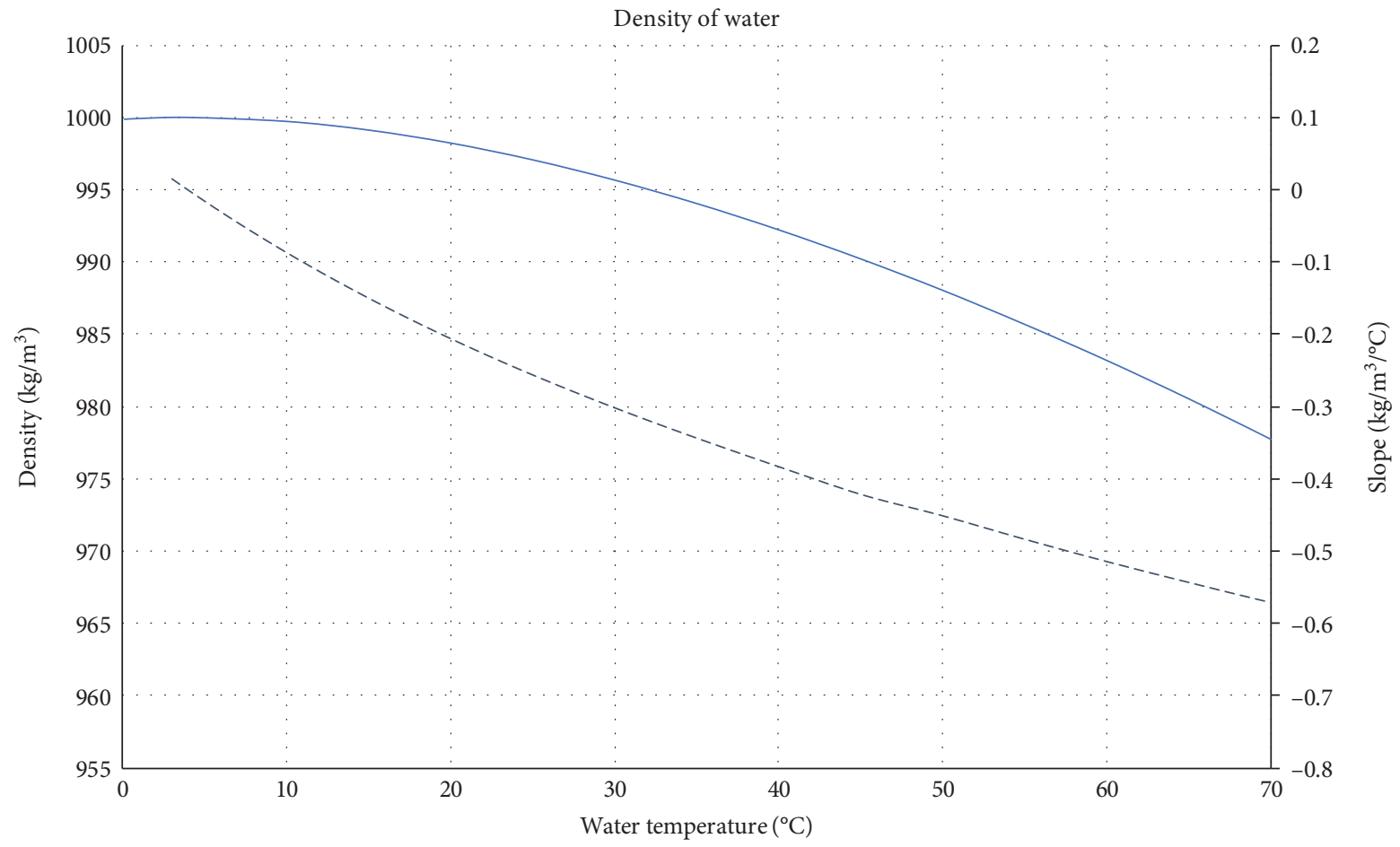

— Density of water

- - - Rate of change of density with temperature

(a)

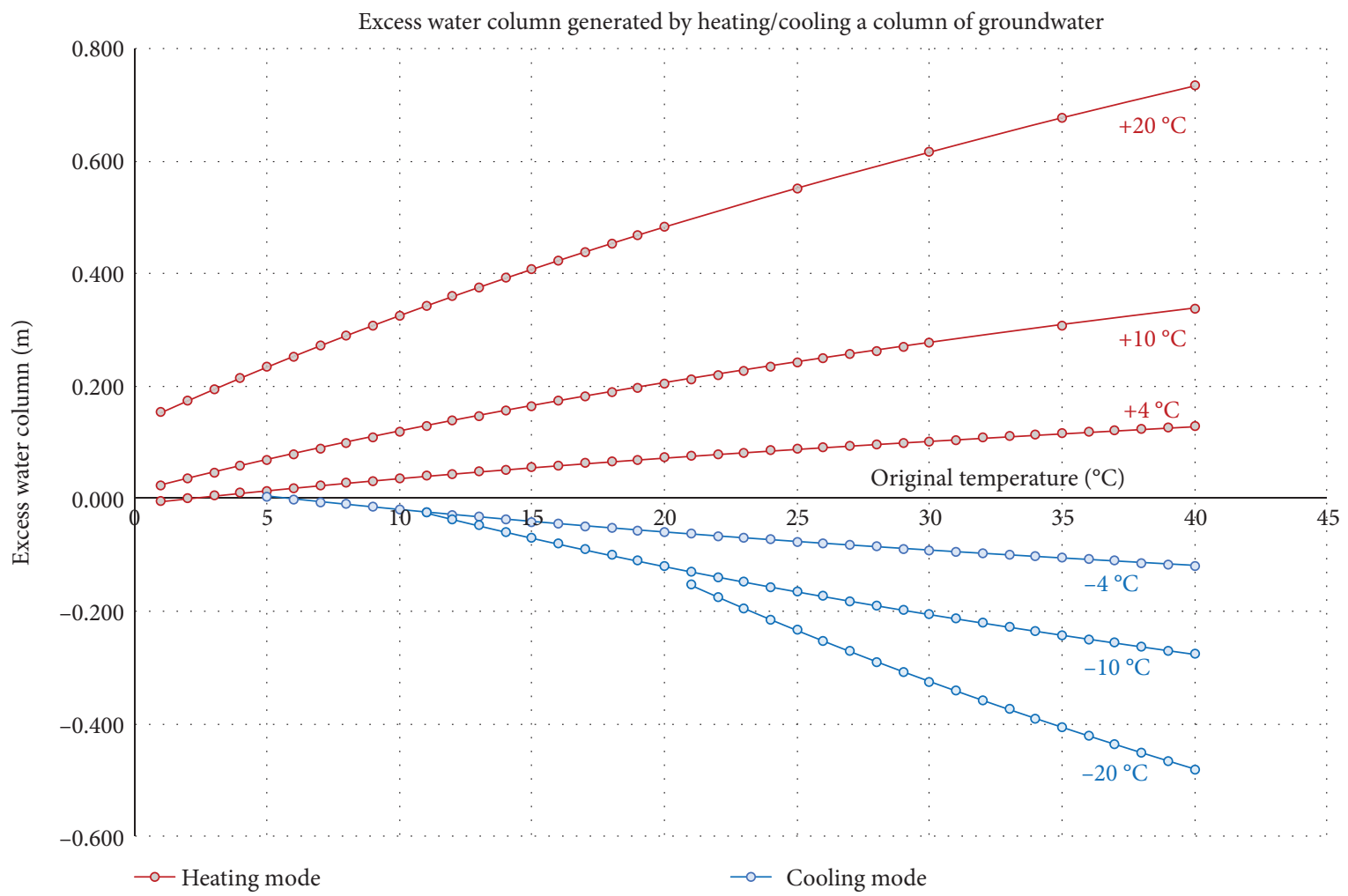

(b)

FIgURE 11: (a) The density of water and its dependence on temperature-based on data from [67, 68]; (b) from this data, it is possible to calculate the excess height of water column caused by heating an $80 \mathrm{~m}$ column of water by $+4,+10$, and $+20^{\circ} \mathrm{C}$, respectively. The blue lines show the height decline caused by cooling the water column. 
enough heat input, it might be possible to induce some degree of convective circulation in the aquifer outside the BHE borehole. Finally, if the water table is deep, the thermosiphon effect can be avoided by keeping the thermally active section of the BHE entirely within the unsaturated zone above the water table.

It will be seen from Figure 11 that the rate of density change increases with increasing temperature, above $4^{\circ} \mathrm{C}$. Thus, in the case of heat rejection:

(i) The greater the temperature difference between the heat transfer fluid and the ambient rock temperature, the greater the likelihood of thermally driven convection or "thermosiphon" developing

(ii) The higher the initial temperature of the rock, the greater the likelihood of thermally driven convection or "thermosiphon" developing

Theoretically, of course, a thermosiphon effect could also develop in cooling mode. However, in practice, because the density of water reaches a maximum at around $+4^{\circ} \mathrm{C}$, the density differences achievable by cooling the groundwater in a borehole from an original temperature of $10^{\circ} \mathrm{C}$ (say) are rather low (see Figure 11(b)). It is only when the original ground temperature exceeds around $15^{\circ} \mathrm{C}$ that significant thermosiphon effects seem likely in heat extraction mode. For this reason, the storage of "coolth" in BHE arrays in permeable fractured rocks is likely to suffer less from thermally driven convective heat losses, than the storage of heat in similar arrays.

Testing of BHEs is typically undertaken by carrying out a thermal response test (TRT) by constant injection of heat and observation of temperature rise (on the assumption that, if heat transfer is predominantly by conduction, the borehole will behave similarly in heat extraction mode). It is found, however, that the thermosiphon effect can lead to significant overestimation of rock thermal conductivity during TRT tests in groundwater-filled BHE in permeable fractured bedrock. In fact, experiments have been carried out [60] on an $80 \mathrm{~m}$ deep, groundwater-filled borehole in fractured rock in Göteborg, Sweden. It was found that at a heat injection rate of $55 \mathrm{~W} \mathrm{~m}^{-1}$, the TRT yielded an estimate of apparent thermal conductivity of $3.19 \mathrm{~W} \mathrm{~m}^{-1} \mathrm{~K}^{-1}$ (believed to be reasonably representative of the "true" conductivity). Increasing the rate to $141 \mathrm{~W} \mathrm{~m}^{-1}$ resulted in a higher apparent thermal conductivity of $3.57 \mathrm{~W} \mathrm{~m}^{-1} \mathrm{~K}^{-1}$, suggesting that $12 \%$ additional heat loss was due to thermally driven convective heat losses to the surrounding aquifer.

While enhanced convective heat transfer between the $\mathrm{BHE}$ heat exchange pipe and the borehole wall will potentially occur in any water-filled borehole (see Free Convection within the BHE Water Column), this will result in more efficient heat transfer in the borehole structure itself (i.e., lower $R_{\mathrm{b}}$ ) and will not lead to greater heat losses from a BTES array. Similarly, a "local" thermosiphon effect, which is not laterally extensive, may have a positive impact in enhancing heat transfer between the borehole and the rocks immediately surrounding it. However, a laterally extensive thermosiphon effect will potentially lead to heat losses from a
BTES, but a prerequisite is that the surrounding rock contains hydraulically connected permeable horizons or fractures [73]. Extensive permeable fractures near the top (or the base) of the water-filled section of the borehole will be particularly disadvantageous as their presence implies that the thermosiphon will affect the entire length of the borehole. In large BTES systems, multiple water-filled boreholes will themselves form vertical conduits interconnecting permeable fractures, and the chances of forming a wellconnected fracture system are enhanced.

Observation clearly suggests that, in many crystalline rock terrains, fracture permeability is typically highest in the uppermost few tens of metres of a hard rock aquifer. This is partly due to the fact that fracture permeability tends to decrease with depth due to increasing loadings (increasing in situ stresses tending to close fracture apertures $[74,75]$ ). More specifically, and especially in the case of northern Europe and Fennoscandia [76, 77], stress-relief fractures and exfoliation joints often develop in the upper few tens of metres of a lithified rock mass, typically approximately parallel to the topography. These are usually ascribed to the removal of an overburden, either by erosion or by melting of a Pleistocene ice sheet and postglacial isostatic uplift. Moreover, it has been demonstrated [78] that the stresses beneath a large ice sheet are sufficient to cause shallow shear failure of crystalline rock. It has also been noted [76] that groundwater flow pathways may often develop as "hydrofractures," where natural fluid pressures exceed the normal compressive stresses on a fracture plane (plus the tensile strength of the rock if a new fracture is initiated). The water pressures developed below and in front of a major glacial ice sheet are sufficient to cause hydraulic fracturing of sediments and the hydraulic opening of shallow fractures within crystalline rock $[78,79]$. Several authors report field evidence of periglacial hydraulic opening of shallow fractures in Fennoscandian crystalline rock [80-83]. For all these reasons, one might suppose that BTES systems in recently glaciated hard-rock terrain might be particularly susceptible to heat loss by thermosiphon effects from open fractures and joints in the shallow portion of a BHE.

\section{Additional Strategies for Efficient Thermal Energy Storage}

Several additional strategies can be incorporated into a BTES system to improve efficiency and to increase flexibility of operation. The simulations of the BTES systems in the previous sections have assumed that all the boreholes of the BTES are connected in parallel and "see" the same heat transfer fluid temperatures and building loads. The system does not, of course, have to be designed in this way. In fact, it has become accepted practice to design cylindrical BTES arrays with two circular header pipes, one around the external circumference of the array and one within the interior of the array. BHEs are then connected in series along radials connecting the two headers. It has been demonstrated above that the optimal design of circular BTES arrays can involve relatively short boreholes, with a depth similar to the lateral extent of the array. This, in turn, implies that connection of 


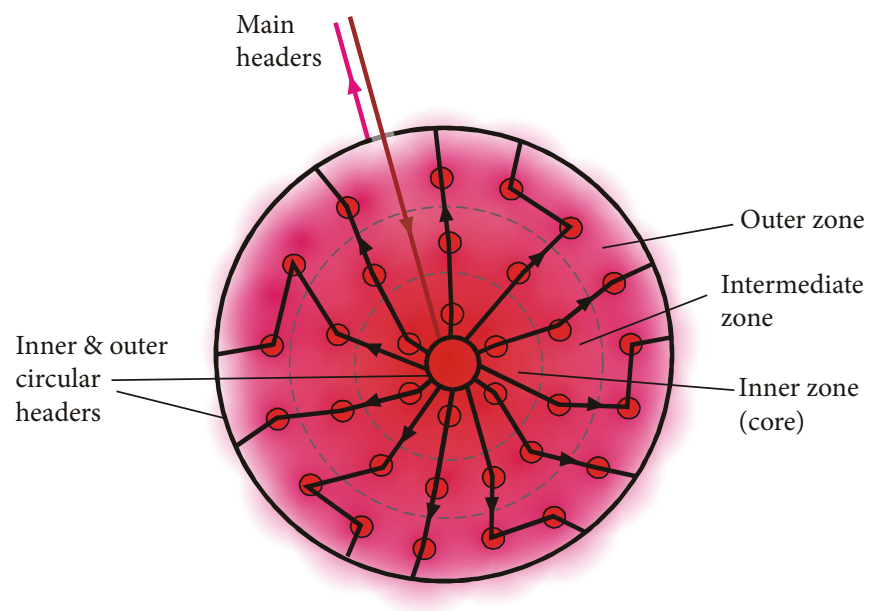

FIGURE 12: Cylindrical BTES being zonally charged with heat via boreholes connected in series along radial subheaders.

several boreholes in series can still result in relatively short hydraulic path lengths without unduly high hydraulic head losses. This arrangement means that the BTES array can be divided into two (or more) concentric thermal zones (Figure 12). Reversing valves can be installed allowing the BTES heat transfer fluid to be directed from the outer circumferential header to the inner one, or vice versa. For example, in a BTES designed to store heat, when surplus heat is available (e.g., during hot summer days), the hot heat transfer fluid is directed towards the core of the BTES, which is warmed to the highest temperature, and then radially outwards, progressively warming the outer zones. When there is a heat demand, the cool heat transfer fluid is circulated from the outer circumferential header first and progressively inwards towards the inner header. Thus, the fluid is initially "prewarmed" by heat acquired from the BHEs in the outer zone of rock and finally is heated by the core of the BTES array to its full temperature. In this way, the core of the array is always "charged" with heat first and discharged last; the core is also always surrounded by the warm rock/sediment of the outer zones and tends to retain its heat most efficiently.

In a BTES in a warm region, where the predominant need is to store "coolth" rather than heat, a similar strategy is applied. On cold winter days, dry coolers may discharge heat to the cold air (this is effectively equivalent to harvesting "coolth" from the atmosphere); the resulting cold heat transfer fluid will be passed first to the inner header, to cool down ("charge") the inner core of the array and then pass radially outward to the perimeter. When there is a demand for cooling, the warm heat transfer fluid will circulate first to the outside circumferential header (where heat can most efficiently be dispersed into the surrounding rock through the perimeter surface of the BTES) and flow towards the cold core, such that cold heat transfer fluid can be returned to the building [43].

The adequate simulation of such "zoned" BTES systems is beyond the capabilities of conventional BHE simulators [43] (such as Earth Energy Designer) and requires more sophisticated modelling tools such as TRNSYS $[84,85]$ or even finite element models such as FEFLOW [66].

\section{Supplementary Strategies to BTES}

BTES are particularly suited to long-term thermal energy storage, because they can access a volume and thermal capacity of rock or sediment that dramatically exceeds that available to most surface-engineered thermal stores. BTES can also be used for short-term storage of heat. However, the expense of drilling boreholes, and the fact that it is rather difficult to achieve more than $50 \%$ heat recovery from a BTES, it is often more cost-effective to use a surface-engineered structure for storage of short-term (e.g., diurnal) surpluses of heat and "coolth." Such a store can feasibly be constructed to accommodate smaller quantities of heat and can be thermally insulated to minimise heat losses and improve recoverability. In situations where the supply of waste heat is variable in temperature or very "peaky," a surface thermal store can be used as a "buffer" from which a more regulated supply of heat at a constant temperature can be injected to the ground for long-term storage. With BTES where there is danger of convective loss of heat via a "thermosiphon" effect, the possibility to avoid very high injection temperatures, via the use of a thermal buffer, may also reduce the intensity of convective heat loss.

The most fundamental thermal energy storage is simply a surface tank or buried pit of warm or cold water (tank or pit thermal energy storage-TTES or PTES). This can be readily insulated; water has a huge volumetric heat capacity $\left(4.19 \mathrm{MJ} \mathrm{m}^{-3} \mathrm{~K}^{-1}\right)$, while its fluid nature means that heat can readily be distributed to, from, and within the store. The fact that water has a low viscosity means, however, that free convection within a tank can readily occur, meaning that thermal stratification within a single tank may be difficult to maintain.

Alternative surface (or buried in the shallow subsurface) thermal energy stores can include [51] 
(i) phase change media (PCMs, including ice) where surplus thermal energy is stored in the form of latent heat, for example, by melting or freezing the material in question [86-90]

(ii) Thermochemical heat storage (THS- $[91,92])$, whereby heat is stored or released during the chemical interaction between two materials (often two liquids or a solid and a vapour); the nature of this interaction may be physical sorption, chemical sorption, or true chemical reaction

(iii) Dynamic thermal energy storages (DTES- $[93,94])$, which is aimed not only at storing heat and coolth but also at storing heat at varying temperatures simultaneously, for example, by maintaining a thermal stratification within the store. One example of a DTES is a tank of water filled with a porous medium and then saturated with water. The porous medium hinders the formation of free convection cells and allows thermal stratification in the tank

Indeed, a BTES can be considered as only one component of an integrated thermal energy network, providing longterm (seasonal) thermal storage, while a surface-engineered store provides short-term (diurnal) thermal energy storage [94] and a network of pipes of heat transfer fluid, heat exchangers, and heat pumps connect various sources or sinks of heat, e.g.,

(i) deliberate harvesting of solar or atmospheric heat and "coolth" - via dry coolers or thermal solar cells

(ii) lakes, rivers, or the sea

(iii) buildings, which may be producers (via air conditioning) or consumers of heat

(iv) industrial processes

(v) power stations or combined heat and power (CHP) plants

(vi) waste incinerators (which may also generate electrical power)

Several of the above are heat sources that would otherwise discharge their surplus heat to waste, resulting in $100 \%$ thermal losses. Thus, large-scale BTES offers a remarkable potential to store this waste heat until a time of demand; even if the BTES is only $40 \%$ efficient, this still represents a very significant thermal gain.

Horticultural greenhouse complexes provide particularly attractive opportunities to implement integrated thermal energy networks, incorporating storage elements [95, 96]. Modern "closed" greenhouse concepts are typically kept sealed from the external atmosphere to minimise exposure to pests; as such, they may require space cooling on hot summer days, dehumidification (essentially, a cooling process removing latent heat of condensation), and space heating in the winter. They may even incorporate combined heat and power (CHP) plants to produce electricity for winter lighting, surplus heat for winter heating, and excess $\mathrm{CO}_{2}$ (from fuel combustion) to enrich the greenhouse atmosphere. In such situations, one can readily imagine that there will be seasonal heat surpluses (summer cooling and dehumidification) and winter heat deficits (winter heating) that can be satisfied by long-term seasonal heat storage in a BTES. There will also be short-term heat surpluses and deficits (e.g., spring and winter diurnal surpluses, where cold nights, requiring heating, alternate with hot days, requiring cooling); these can be satisfied by shunting heat to and from a short-term surficial dynamic thermal energy store. If heat or coolth surpluses or deficits become so large that they cannot be meaningfully stored, they can be discharged to the atmosphere (or surface waters) via heat exchangers, such as dry coolers. An example of such a greenhouse complex, employing smart controls, several sources and sinks of heat and thermal energy storage can be found at Mære, Trøndelag, Norway [73, 96-99].

\section{Conclusions}

Borehole thermal energy storage (BTES) is a technological concept which is proven to allow seasonal storage of large quantities of heat in large volumes of rock or sediment by the use of borehole heat exchangers (BHE). Two broad conceptual types of BTES are used:

(i) High-temperature (typically $>40^{\circ} \mathrm{C}$ ) BTES, where waste heat from an industrial process (e.g., metallurgical industry), waste incineration, combined heat, and power or solar thermal harvesting is deliberately stored from seasons of low demand to seasons of high demand (winter). In such schemes, the initial years of operation are typically used to «charge up» or condition the BTES to its operating temperature. When a long-term quasi-steady state has been achieved, heat is recharged and recovered on an annual cycle and long-term temperatures remain relatively constant

(ii) Ambient temperature BTES, where waste heat, typically from space cooling, is rejected to the ground during summer, warming it up to $10-20^{\circ} \mathrm{C}$ higher than ambient temperature. During winter, this heat is extracted, typically via the use of heat pumps, for space heating, thus prechilling the ground (storing "coolth") ready for the summer cooling season. If the recharge and extraction of heat are balanced, the BTES temperatures remain stable year on year and temperature extremes are avoided, allowing for very efficient heat pump operation

Particular attention should be paid to the design of BTES arrays; the fundamental mathematics, design principles, and optimisation of BTES arrays have already been clearly developed and documented by Swedish researchers several decades ago $[3,16,17]$. Several key design considerations should be remembered:

(i) The geometric shape of the BTES should be optimised to maximise internal volume and 
minimise external surface areas: thus, equidimensional cylindrical and cubic arrays of BHE are especially efficient. The surface area/volume ratio (and hence heat losses) decrease as size increases. This is especially important for high-temperature BTES

(ii) The top surface of the BTES is especially susceptible to losing heat; thus, consideration should be given to insulating it, especially for high-temperature BTES

(iii) The more boreholes in the BTES, the more efficient the transfer of heat to and from the BTES and the more closely the average BTES temperature approaches the source/sink temperature

(iv) The greater the rock thermal conductivity and the lower the borehole thermal resistance, the fewer $\mathrm{BHE}$ are required to achieve optimal heat transfer efficiency (and the greater the acceptable spacing between them)

(v) Zonation and managed charging and discharging of large BTES can optimise efficiency [43]

(vi) Some drilling methods (e.g., down-the-hole hammer) can result in very significant borehole deviations (e.g., $1 \mathrm{~m}$ horizontal in $10 \mathrm{~m}$ vertical), which can lead to unpredictable borehole spacings or intersections at depth in a BTES

(vii) Simple analytical methods and optimisation routines $[3,17]$ are adequate for the outline design of many BTES. For detailed simulation of simple systems, analytical programs such as Earth Energy Designer [49] will be valuable, but as complexity increases, more complex programs such as TRNSYS [85] or finite element codes [66] may be required

Additionally, specifically for high-temperature BTES:

(viii) Thermal storage efficiency increases as the size of the BTES increases. In Sweden, thermal recovery factors exceeding $50 \%$ are only predicted a heat extraction capacity of $1 \mathrm{GWh} /$ year [3]

(ix) For a high thermal recovery factor, the annual recharge and extraction must be significantly larger than the steady-state heat loss (for a thermal recovery factor $>30 \%$, the ratio of peak discharge rate to steady state heat loss should exceed 3.7 [17])

This paper has focussed also on an understanding of convective and advective processes:

(i) Where hydrogeology and geotechnical considerations allow, groundwater filled open-hole BHE allow free convection cells to develop, resulting in enhanced heat transfer within a BTES and lower borehole thermal resistance, compared with a grout-backfilled borehole. The use of single pipe coaxial borehole heat exchange can result in extremely low borehole thermal resistance

(ii) The presence of natural groundwater flow through a BTES array is generally regarded as negative for the efficient recovery of heat. Darcy fluxes in excess of a few $\mathrm{cm} \mathrm{day}^{-1}$ may lead to significant heat losses. High groundwater fluxes are typically associated with high topographic gradients, nearby groundwater pumping and high hydraulic conductivities. Casing can be extended downhole to exclude permeable horizons or fractures, or conductive fractures can be grouted during drilling, to reduce groundwater throughflow, but both of these are achieved at significant costs

(iii) Heating of natural groundwater in and around a BHE can result in a convection cell forming-a socalled thermosiphon. If laterally extensive, such a thermosiphon effect can lead to loss of stored heat. If local to the BHE, it may simply result in more efficient heat transfer in the BTES array. The likelihood of thermosiphon effects increases as the ground temperature increases and as the differential between $\mathrm{BHE}$ and ambient ground temperature increases. The likelihood of thermosiphons developing is less likely where "coolth" is being stored (i.e., heat is being extracted)

Both experience and theoretical considerations suggest that thermal recovery advantages or efficiencies exceeding $40 \%$ are rather difficult to achieve with BTES technology. This does not mean that BTES is a compromised concept, however. A thermal advantage or recovery of even $30-40 \%$ is valuable, when the alternative is to simply throw heat away as a valueless waste product.

In many European cities, disposal of waste heat from space cooling and air conditioning can be difficult and costly. Thus, if this "waste" heat can be recharged to the ground and stored with even a modest thermal storage efficiency and/or coupled to a balanced winter thermal demand, it can secure a dynamic thermal equilibrium within a BTES, allowing summer ground sourced space cooling and winter ground sourced space heating to be performed without extreme temperatures being reached. The BTES maintains a relatively high ground temperature in winter, thus ensuring that the evaporator temperature in a heat pump used for winter space heating remains several ${ }^{\circ} \mathrm{C}$ higher than it would have been without BTES. This can have a significant impact on the coefficient of performance of the heat pump and can dramatically improve overall energy efficiency.

Although BTES can be used for short-term energy storage, it is especially suited to seasonal storage of heat, due the ground's enormous thermal capacity. Short-term heat storage is arguably better accomplished via tank, phase-change, or thermochemical or dynamic thermal energy storage (DTES). Such short-term storage strategies can also complement longer-term seasonal BTES storage by acting as thermal "capacitors," evening out peaks in supply and demand. 
Most importantly, a BTES should not be regarded in isolation, but merely one component (a high-capacity seasonal accumulator) within a district heating and cooling network, where networks of heat transfer pipes connect sources of heat (industries, CHP plants, waste incinerators, space cooling, and solar thermal harvesting) and "coolth" (winter dry coolers, cold lakes, and marine environments), loci of demand for heating and cooling, and short- and long-term seasonal storage.

\section{Conflicts of Interest}

The authors declare that they have no conflicts of interest.

\section{References}

[1] D. Banks, "An introduction to 'thermogeology' and the exploitation of ground source heat," Quarterly Journal of Engineering Geology and Hydrogeology, vol. 42, no. 3, pp. 283-293, 2009.

[2] D. Banks, An Introduction to Thermogeology: Ground Source Heating and Cooling, John Wiley \& Sons, Chichester, UK, 2nd edition, 2012.

[3] B. Nordell, Borehole Heat Store Design Optimization, [Ph.D. Thesis], Luleå University of Technology, Luleå, Sweden, 1994.

[4] B. Sanner and K. Knoblich, "New IEA-Activity ECES Annex 12: high temperature underground thermal energy storage," in Proceedings of The Second Stockton International Geothermal Conference, Richard Stockton College, NJ, USA, 1998.

[5] G. Hellström, "Ground source heat pumps in Scandinavia - a success story," in Lecture held at the Ground Source Heat Pump Seminar, UK National Energy Foundation, 2005.

[6] G. Hellström, "Borehole heat exchangers," in Geotrainet Manual for Designers of Shallow Geothermal Systems, pp. 31-52, ALTENER - Intelligent Energy Europe Project: IEE/07/581/SI2.499061, Brussels, Belgium, 2011.

[7] M. Malmberg, Transient Modeling of a High Temperature Borehole Thermal Energy Storage Coupled with a Combined Heat and Power Plant, [M.S. Thesis], Kungliga Tekniska Högskolan, Stockholm, Sweden, 2017.

[8] G. Bakema and A. Snijders, "ATES and ground-source heat pumps in the Netherlands," IEA Heat Pump Centre Newsletter, vol. 16, no. 2, pp. 15-17, 1998.

[9] O. Andersson, "ATES for district cooling in Stockholm," in Thermal Energy Storage for Sustainable Energy Consumption, H. Ö. Paksoy, Ed., vol. 234 of NATO Science Series (Mathematics, Physics and Chemistry), pp. 239-243, Springer, Dordrecht, Netherlands, 2007.

[10] M. Godschalk and G. Bakema, "20,000 ATES systems in the Netherlands in 2020 - major step towards a sustainable energy supply," in Proceedings Effstock 2009 - The 11th International Conference on Thermal Energy Storage for Efficiency and Sustainability, Stockholm, Sweden, 2009.

[11] F. J. Molz, J. C. Warman, and T. E. Jones, “Aquifer storage of heated water: part I - a field experiment," Ground Water, vol. 16, no. 4, pp. 234-241, 1978.

[12] F. J. Molz, J. G. Melville, A. D. Parr, D. A. King, and M. T. Hopf, "Aquifer thermal energy storage : a well doublet experiment at increased temperatures," Water Resources Research, vol. 19, no. 1, pp. 149-160, 1983.

[13] O. Andersson, "The ATES project at Stockholm Arlanda Airport - technical design and environmental assessment," in
Proceedings Effstock 2009 - The 11th International Conference on Thermal Energy Storage for Efficiency and Sustainability, Stockholm, Sweden, 2009.

[14] L. Wigstrand, "The ATES project-a sustainable solution for Stockholm-Arlanda airport," in Proceedings Effstock 2009 The 11th International Conference on Thermal Energy Storage for Efficiency and Sustainability, Stockholm, Sweden, 2009.

[15] G. Van Meurs, Seasonal Heat Storage in the Soil, [Ph.D. Thesis], University of Technology Delft, Delft, Netherlands, 1985.

[16] J. Claesson, B. Eftring, P. Eskilson, and G. Hellström, Markvärme: en handbok om termiska analyser: Del 1-3 [Ground source heat: a handbook of thermal analyses: Part 1-3 - in Swedish]. BFR T-skrift vol. T16-18:1985, Byggforskningsrådet (BFR), Stockholm, Sweden, 1985.

[17] G. Hellström, Ground Heat Storage: Thermal Analyses of Duct Storage Systems. 1: Theory, University of Lund, Lund, Sweden, 1991.

[18] B. Sibbitt, T. Onno, D. McClenahan et al., "The Drake Landing solar community project-early results," in Proceedings of the 32nd Annual Conference of the Solar Energy Society of Canada, pp. 10-14, Calgary, Alberta, Canada, 2007.

[19] B. Sibbitt, D. McClenahan, R. Djebbar et al., "The performance of a high solar fraction seasonal storage district heating system - five years of operation," Energy Procedia, vol. 30, pp. 856$865,2012$.

[20] DLSC, "Drake Landing solar community website," 2018, http://www.dlsc.ca/index.htm.

[21] M. Lundh and J. O. Dalenbäck, "Swedish solar heated residential area with seasonal storage in rock: initial evaluation," Renewable Energy, vol. 33, no. 4, pp. 703-711, 2008.

[22] J. Nussbicker, W. Heidemann, and H. Mueller-Steinhagen, "Monitoring results and operational experiences for a central solar district heating system with borehole thermal energy store in Neckarsulm (Germany)," in Proceedings of the 10th International Conference on Thermal Energy Storage, ECOSTOCK 2006, Richard Stockton College, NJ, USA, 2006.

[23] H. Seiwald, E. Hahne, and M. Reuss, "Underground seasonal heat storage for a solar heating system in Neckarsulm, Germany," Bulletin d'Hydrogéologie, vol. I7, pp. 349-357, 1999.

[24] L. Stiles, "Underground thermal energy storage in the U.S," IEA Heat Pump Center Newsletter, vol. 16, no. 2, pp. 22-23, 1998.

[25] E. Thuresson, Systematisk sammanställning av större geoenergianläggningar $i$ Sverige [Systematic comparison of larger geoenergy installations in Sweden], [M.S. thesis], Lund University, Lund, Sweden, 2014.

[26] A. Christianssen, "En sommer går under jorda [A summer is stored underground]," 2011, https://forskning.no/fysikkmiljoteknologi/2011/12/en-sommer-gar-under-jorda.

[27] U. Prestegaard, "Analyse av det grunnvarmebasertevarmepumpesystemetmed termisk lager på Ljan skole [Analysis of the ground source heat pump systemwith thermal storage at Ljan school]," [Accessed 223 2019], 2013, https://www .sintef.no/globalassets/project/interact/prosjektoppg_una_ prestegaard_2013-analyse-av-det-grunnvarmebasertevarmepumpesystemet-med-termisk-lager-pa-ljan-skole.pdf.

[28] X. Q. Zhai and Y. Yang, "Experience on the application of a ground source heat pump system in an archives building," Energy and Buildings, vol. 43, no. 11, pp. 3263-3270, 2011.

[29] B. Nordell, O. Andersson, L. Rydell, and A. Liuzzo-Scorpo, "Long-term performance of the HT-BTES in Emmaboda, 
Sweden," in Proceedings of the 13th International Conference on Underground Thermal Energy Storage - "GreenStock 2015”, Beijing, China, 2015.

[30] B. Nordell, A. Liuzzo Scorpo, O. Andersson, L. Rydell, and B. Carlsson, The HT BTES Plant in Emmaboda - Operation and Experiences 2010-2015, Luleå University of Technology, Luleå, Sweden, 2016.

[31] H. Ohga and K. Mikoda, "Energy performance of borehole thermal energy storage systems," in Proceedings of the 7th International IBPSA Conference "Building Simulation", pp. 1009-1016, Rio de Janeiro, Brazil, 2001.

[32] K. S. Lee, "Performance of open borehole thermal energy storage system under cyclic flow regime," Geosciences Journal, vol. 12, no. 2, pp. 169-175, 2008.

[33] S. Lanini, F. Delaleux, X. Py, R. Olivès, and D. Nguyen, "Improvement of borehole thermal energy storage design based on experimental and modelling results," Energy and Buildings, vol. 77, pp. 393-400, 2014.

[34] Q. Zheng, Design of a High Temperature Subsurface Thermal Energy Storage System, [M.S. Thesis], Clemson University, Clemson, SC, USA, 2014.

[35] L. Gao, J. Zhao, and Z. Tang, "A review on borehole seasonal solar thermal energy storage," Energy Procedia, vol. 70, pp. 209-218, 2015.

[36] A. Hesaraki, S. Holmberg, and F. Haghighat, "Seasonal thermal energy storage with heat pumps and low temperatures in building projects-a comparative review," Renewable and Sustainable Energy Reviews, vol. 43, pp. 1199-1213, 2015.

[37] O. Kizilkan and I. Dincer, "Borehole thermal energy storage system for heating applications: thermodynamic performance assessment," Energy Conversion and Management, vol. 90, pp. 53-61, 2015.

[38] M. Reuss, "The use of borehole thermal energy storage (BTES) systems," in Advances in Thermal Energy Storage Systems - Methods and Applications, L. Cabeza, Ed., pp. 117147, Woodhead Publishing, Cambridge, UK, 2015.

[39] N. Giordano, C. Comina, G. Mandrone, and A. Cagni, "Borehole thermal energy storage (BTES). First results from the injection phase of a living lab in Torino (NW Italy)," Renewable Energy, vol. 86, pp. 993-1008, 2016.

[40] N. Rapantova, P. Pospisil, J. Koziorek, P. Vojcinak, D. Grycz, and Z. Rozehnal, "Optimisation of experimental operation of borehole thermal energy storage," Applied Energy, vol. 181, pp. 464-476, 2016.

[41] K. W. Tordrup, S. E. Poulsen, and H. Bjørn, “An improved method for upscaling borehole thermal energy storage using inverse finite element modelling," Renewable Energy, vol. 105, pp. 13-21, 2017.

[42] B. Welsch, L. Göllner-Völker, D. O. Schulte, K. Bär, I. Sass, and L. Schebek, "Environmental and economic assessment of borehole thermal energy storage in district heating systems," Applied Energy, vol. 216, pp. 73-90, 2018.

[43] C. Hammock, "Borehole thermal energy storage: it's time to move geothermal heat pump systems forward," 2018, https://www.phcppros.com/articles/6989-borehole-thermalenergy-storage.

[44] P. Eskilson, Thermal Analysis of Heat Extraction Boreholes, [Ph.D. Thesis], University of Lund, Lund, Sweden, 1987.

[45] D. Banks, "Horatio Scott Carslaw and the origins of the well function and line source heat function," Scottish Journal of Geology, vol. 51, no. 1, pp. 100-104, 2015.
[46] S. Whitehead, "Determining temperature distribution: a contribution to the evaluation of the flow of heat in isotropic media," The Electrician, pp. 225-226, 1927.

[47] C. V. Theis, "The relation between the lowering of the piezometric surface and the rate and duration of discharge of a well using ground-water storage," Transactions, American Geophysical Union, vol. 16, no. 2, p. 519, 1935.

[48] E. Kjellsson, G. Hellström, and B. Perers, "Optimization of systems with the combination of ground-source heat pump and solar collectors in dwellings," Energy, vol. 35, no. 6, pp. 2667-2673, 2010.

[49] T. Blomberg, J. Claesson, P. Eskilson, G. Hellström, and B. Sanner, Earth Energy Designer (EED) Version 3.22, Blocon Software, Lund, Sweden, 2016.

[50] H. Midttveit, Numerisk modellering av varmeoverskudd $i$ grunnvarmeanlegg - Konsekvenser og forebyggende tiltak [Numerical modelling of excess heat in ground source heat pump systems - consequences and preventive measures], [M.S. thesis], University of Bergen/Høgskulen på Vestlandet, Bergen, Norway, 2018.

[51] Delta Energy and Environment, "Evidence gathering: thermal energy storage (TES) technologies," Report for the UK Department for Business, Energy and Industrial Strategy, 2016.

[52] L. Krige, "Borehole temperatures in the Transvaal and Orange Free State," Proceedings of the Royal Society of London. Series A. Mathematical and Physical Sciences, vol. 173, no. 955, pp. 450-474, 1939.

[53] P. E. Gretener, "On the thermal instability of large diameter wells-an observational report," Geophysics, vol. 32, no. 4, pp. 727-738, 1967.

[54] E. L. Cussler, Diffusion: Mass Transfer in Fluid Systems, Cambridge University Press, Cambridge, UK, 2009.

[55] S. Berthold, "Synthetic convection log - characterization of vertical transport processes in fluid-filled boreholes," Journal of Applied Geophysics, vol. 72, no. 1, pp. 20-27, 2010.

[56] B. Misstear, D. Banks, and L. Clark, Water Wells and Boreholes, Wiley, Chichester, UK, 2nd edition, 2017.

[57] D. Vroblesky, C. Casey, and M. Lowery, Influence of in-well convection on well sampling, U.S. Geological Survey Scientific Investigations Report 2006-5247, Reston, VA, USA, 2006.

[58] C. Regander, Termiska responstester och dimensionering bergvärmeanläggningar; Resultat av förundersökningar. SWECO report from Uppdrag 1240480, for Jarðfeingi (Faroese Earth and Energy Directorate), SWECO Environment AB, Malmö, Sweden, 2008.

[59] S. Javed and P. Fahlén, "Thermal response testing of a multiple borehole ground heat exchanger," International Journal of Low-Carbon Technologies, vol. 6, no. 2, pp. 141-148, 2011.

[60] S. Javed, J. Spitler, and P. Fahlén, "An experimental investigation of the accuracy of thermal response tests used to measure ground thermal properties," ASHRAE Transactions, vol. 117, no. 1, pp. 13-21, 2011.

[61] N. Molina-Giraldo, P. Blum, K. Zhu, P. Bayer, and Z. Fang, "A moving finite line source model to simulate borehole heat exchangers with groundwater advection," International Journal of Thermal Sciences, vol. 50, no. 12, pp. 2506-2513, 2011.

[62] D. Banks, "A review of the importance of regional groundwater advection for ground heat exchange," Environmental Earth Sciences, vol. 73, no. 6, pp. 2555-2565, 2015.

[63] I. Martinez, "Heat conduction," 2013, http://webserver.dmt. upm.es/ isidoro/. 
[64] H. Carslaw and J. Jaeger, Conduction of Heat in Solids, Clarendon Press, Oxford, UK, 2nd edition, 1959.

[65] L. Ingersoll, O. Zobel, and A. Ingersoll, Heat Conduction, with Engineering, Geological and Other Applications, University of Wisconsin Press, Madison, WI, USA, 1954.

[66] H. Diersch, FEFLOW - Finite Element Modeling of Flow, Mass and Heat Transport in Porous and Fractured Media, Springer, Berlin-Heidelberg, 2014.

[67] F. E. Jones and G. L. Harris, "ITS-90 density of water formulation for volumetric standards calibration," Journal of Research of the National Institute of Standards and Technology, vol. 97, no. 3, pp. 335-340, 1992.

[68] Engineering Toolbox, "Water - density, specific weight and thermal expansion coefficient," 2018, https://www.enginee ringtoolbox.com/water-density-specific-weight-d_595.html.

[69] S. E. A. Gehlin, G. Hellström, and B. Nordell, "The influence of the thermosiphon effect on the thermal response test," Renewable Energy, vol. 28, no. 14, pp. 2239-2254, 2003.

[70] A. Gustafsson, Thermal Response Test - Numerical Simulations and Analyses, [Ph.D. Thesis], Luleå University of Technology, Luleå, Sweden, 2006.

[71] Z. Wang, M. McClure, and R. Horne, "A single well EGS configuration using a thermosiphon. Paper SGP-TR-187," in Proceedings of the 34th Workshop on Geothermal Reservoir Engineering, Stanford, CA, USA, 2009.

[72] A.-M. Gustafsson, L. Westerlund, and G. Hellström, "CFDmodelling of natural convection in a groundwater-filled borehole heat exchanger," Applied Thermal Engineering, vol. 30, no. 6-7, pp. 683-691, 2010.

[73] H. Liebel, Influence of Groundwater on Measurements of Thermal Properties in Fractured Aquifers, [Ph.D. Thesis], Norwegian University of Science and Technology, Trondheim, Norway, 2012.

[74] A. Carlsson and T. Olsson, "Hydraulic properties of Swedish crystalline rocks. Hydraulic conductivity and its relation to depth," Bulletin of the Geological Institutions of the University of Uppsala, N.S., vol. 7, pp. 71-84, University of Uppsala, 1977.

[75] D. Holmes, Hydraulic Testing of Deep Boreholes at Altnabreac: Development of the Testing System and Initial Results, Institute of Geological Sciences, 1981.

[76] A. Gudmundsson, I. Fjeldskaar, and O. Gjesdal, "Fracturegenerated permeability and groundwater yield in Norway," Norges Geologiske Undersøkelse Bulletin, vol. 439, pp. 61-69, 2002.

[77] D. Banks and N. Robins, An Introduction to Groundwater in Crystalline Bedrock, Norges geologiske undersøkelse, Trondheim, Norway, 2002.

[78] G. S. Boulton and P. Caban, "Groundwater flow beneath ice sheets: part II - its impact on glacier tectonic structures and moraine formation," Quaternary Science Reviews, vol. 14, no. 6, pp. 563-587, 1995.

[79] E. Ravier and J. Buoncristiani, "Chapter 12 - glaciohydrogeology," in Past Glacial Environments, pp. 431-466, Elsevier, Amsterdam, Netherlands, 2nd edition, 2018.

[80] R. Pusch, L. Börgesson, and S. Knutsson, "Origin of silty fracture fillings in crystalline bedrock," Geologiska Föreningen $i$ Stockholm Förhandlingar, vol. 112, no. 3, pp. 209-213, 1990.

[81] E. Larsen and J. Mangerud, "Subglacially formed clastic dikes," Sveriges Geologiska Undersökning, Ser, Ca, vol. 81, pp. 163170, 1992.
[82] B. Leijon, Forsmark Site Investigation Investigations of Superficial Fracturing and Block Displacements at Drill Site 5. SKB Report P-05-199, Svensk Kärnbränslehantering AB, Stockholm, Sweden, 2005.

[83] A. Carlsson and R. Christiansson, Construction Experiences from Underground Works at Forsmark Compilation Report, Stockholm, Svensk Kärnbränslehantering AB, Stockholm, Sweden, 2007.

[84] C. Pascual, A. Martinez, M. Epelde, R. Marx, and D. Bauer, "Dynamic modeling of seasonal thermal energy storage systems in existing buildings," in Proceedings of the 55th Conference on Simulation and Modelling (SIMS 55), pp. 250-258, Aalborg, Denmark, 2014.

[85] S. Klein, W. Beckman, J. Mitchell et al., TRNSYS 18: a Transient System Simulation Program, University of Wisconsin, Madison, WI, USA, 2017.

[86] B. Zalba, J. M. Marín, L. F. Cabeza, and H. Mehling, "Review on thermal energy storage with phase change: materials, heat transfer analysis and applications," Applied Thermal Engineering, vol. 23, no. 3, pp. 251-283, 2003.

[87] A. Sharma, V. V. Tyagi, C. R. Chen, and D. Buddhi, "Review on thermal energy storage with phase change materials and applications," Renewable and Sustainable Energy Reviews, vol. 13, no. 2, pp. 318-345, 2009.

[88] F. Agyenim, N. Hewitt, P. Eames, and M. Smyth, "A review of materials, heat transfer and phase change problem formulation for latent heat thermal energy storage systems (LHTESS)," Renewable and Sustainable Energy Reviews, vol. 14, no. 2, pp. 615-628, 2010.

[89] D. Zhou, C. Y. Zhao, and Y. Tian, "Review on thermal energy storage with phase change materials (PCMs) in building applications," Applied Energy, vol. 92, pp. 593-605, 2012.

[90] K. Pielichowska and K. Pielichowski, "Phase change materials for thermal energy storage," Progress in Materials Science, vol. 65, pp. 67-123, 2014.

[91] A. H. Abedin and M. A. Rosen, "A critical review of thermochemical energy storage systems," The Open Renewable Energy Journal, vol. 4, no. 1, pp. 42-46, 2011.

[92] A.-J. de Jong, F. Trausel, C. Finck, L. van Vliet, and R. Cuypers, "Thermochemical heat storage - system design issues," Energy Procedia, vol. 48, pp. 309-319, 2014.

[93] H. Gether, J. Gether, K. Nielsen, and S. Rognlien, "Dynamic thermal storage - physical design and systems integration," in Proceedings of the SET2006 - 5th International Conference on Sustainable Energy Technologies, Vicenza, Italy, 2006.

[94] K. Gether, H. Gether, H. Skarphagen, and J. Gether, "Principles of saving energy with dynamic thermal storage," in Proceedings of the ECEEE 2009 Summer Study "Act! Innovate! Deliver! Reducing Energy Demand Sustainably”, pp. 15411546, Stockholm, Sweden, 2009.

[95] A. Vadiee and V. Martin, "Thermal energy storage strategies for effective closed greenhouse design," Applied Energy, vol. 109, pp. 337-343, 2013.

[96] H. Paksoy and B. Beyhan, "22 - thermal energy storage (TES) systems for greenhouse technology," in Advances in Thermal Energy Storage Systems - Methods and Applications, pp. 533548, Woodhead Publishing, 2015.

[97] M. Stølen, Heat from the Ground and Sun: An EnergyOptimizing Project at More Landbruksskole, [M.S. Thesis], Norwegian University of Science and Technology, Trondheim, Norway, 2010. 
[98] H. Hopen, Prosjektering og konstruksjon av testmodell og styresystem til et fornybart energisystem [Design and construction of test model and control system for a renewable energy system - in Norwegian], [M.S. thesis], Norwegian University of Science and Technology, Trondheim, Norway, 2013.

[99] Mære Landbruksskole, "Varmelageret på Mære landbruksskole [The heat store at Mære Agricultural College - in Norwegian]. Video documentary," April 2018, 2017, https://youtu .be/e92uuXjak88. 

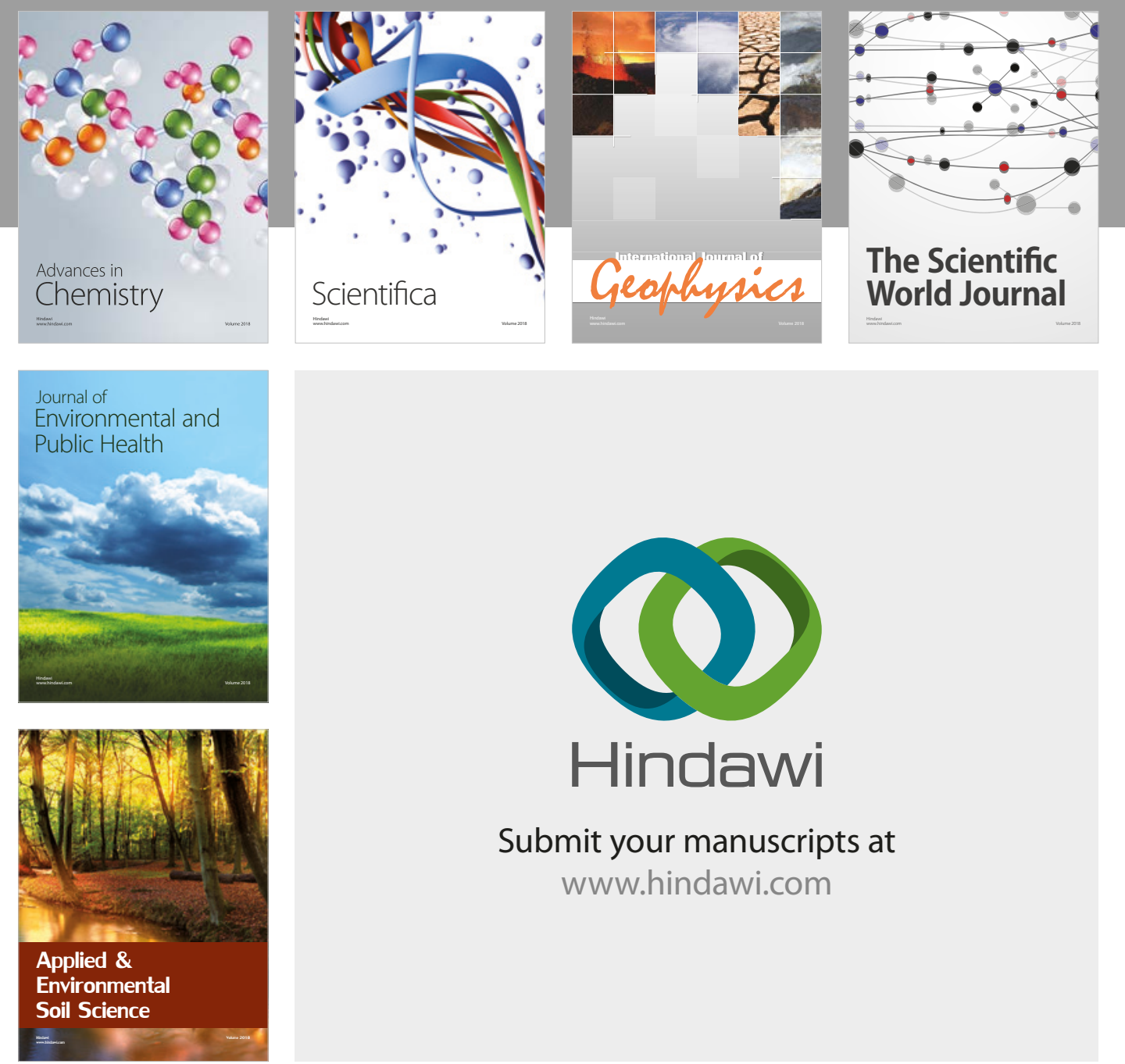

The Scientific

\section{World Journal}
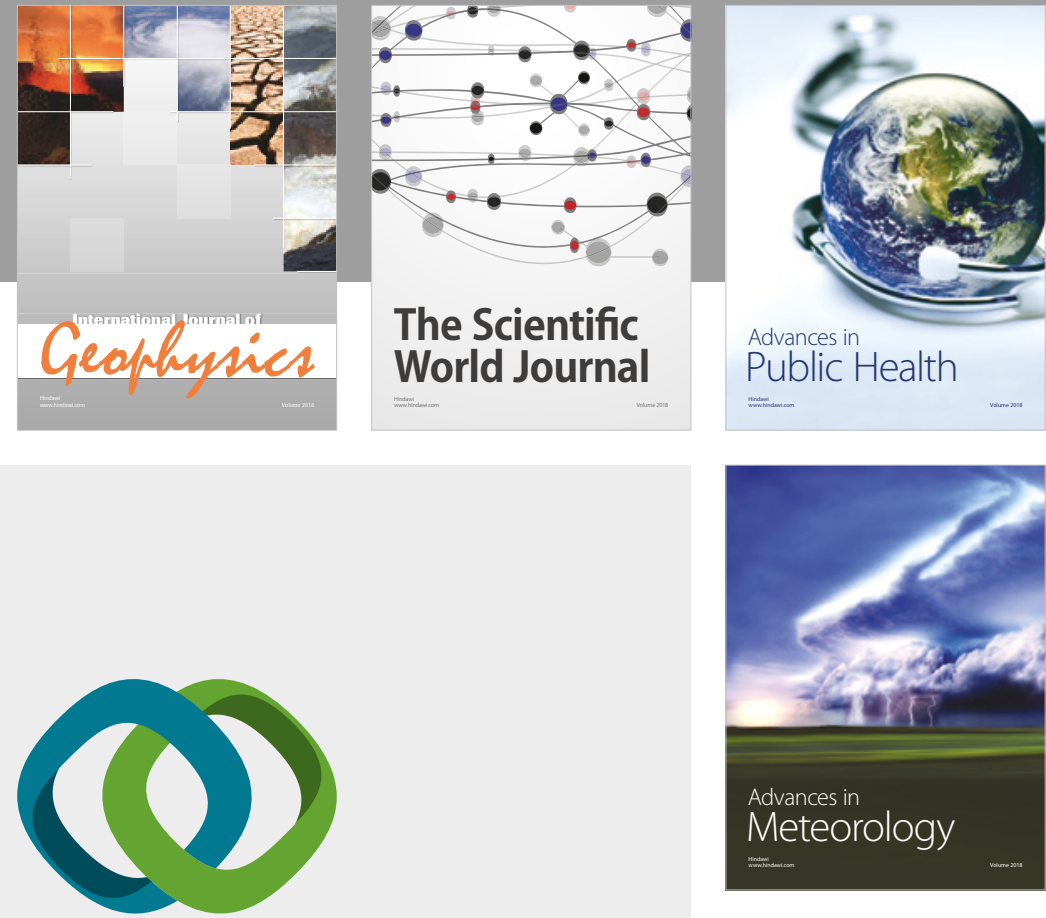

Advan

Public Health

\section{Hindawi}

Submit your manuscripts at

www.hindawi.com
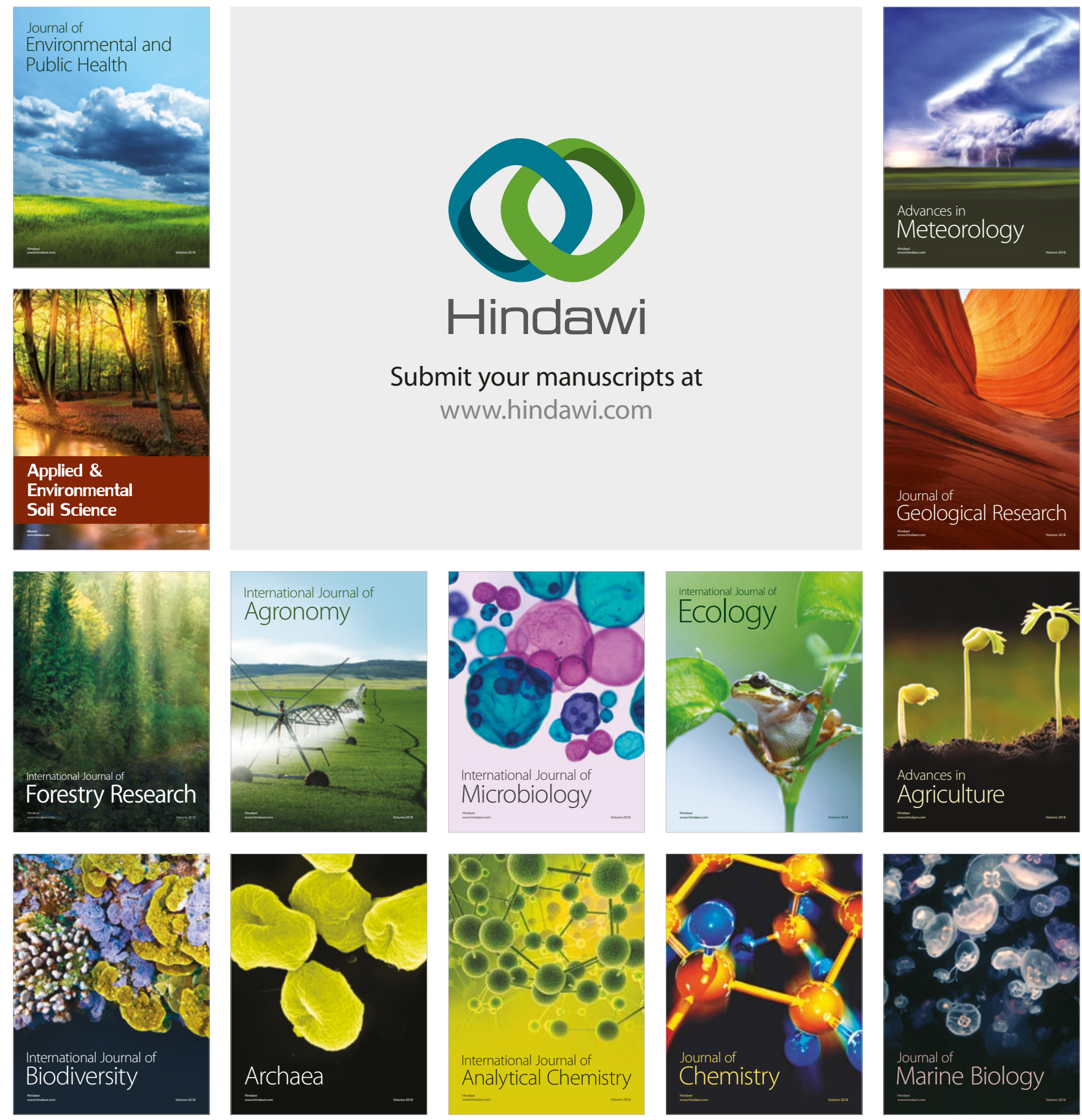